\title{
Cardiovascular health impacts of wildfire smoke exposure
}

\author{
Hao Chen $^{1^{*}}$, James M. Samet ${ }^{2}$, Philip A. Bromberg ${ }^{3}$ and Haiyan Tong $^{2^{*}}$ [D
}

\begin{abstract}
In recent years, wildland fires have occurred more frequently and with increased intensity in many fire-prone areas. In addition to the direct life and economic losses attributable to wildfires, the emitted smoke is a major contributor to ambient air pollution, leading to significant public health impacts. Wildfire smoke is a complex mixture of particulate matter (PM), gases such as carbon monoxide, nitrogen oxide, and volatile and semi-volatile organic compounds. PM from wildfire smoke has a high content of elemental carbon and organic carbon, with lesser amounts of metal compounds. Epidemiological studies have consistently found an association between exposure to wildfire smoke (typically monitored as the PM concentration) and increased respiratory morbidity and mortality. However, previous reviews of the health effects of wildfire smoke exposure have not established a conclusive link between wildfire smoke exposure and adverse cardiovascular effects. In this review, we systematically evaluate published epidemiological observations, controlled clinical exposure studies, and toxicological studies focusing on evidence of wildfire smoke exposure and cardiovascular effects, and identify knowledge gaps. Improving exposure assessment and identifying sensitive cardiovascular endpoints will serve to better understand the association between exposure to wildfire smoke and cardiovascular effects and the mechanisms involved. Similarly, filling the knowledge gaps identified in this review will better define adverse cardiovascular health effects of exposure to wildfire smoke, thus informing risk assessments and potentially leading to the development of targeted interventional strategies to mitigate the health impacts of wildfire smoke.
\end{abstract}

Keywords: Wildfire smoke, Wood smoke, Air pollution, Cardiovascular health

\section{Introduction}

Wildland fires have been an important factor in shaping the landscape and controlling the biomes on Earth for millions of years [115]. Over recent decades, rapid growth of the wildland-urban interface and anthropogenic climate change have contributed to increased wildfire frequency and unprecedented intensity in many fire-prone regions $[1,22,117,163$, 169]. In the western United States, summer wildfire frequency increased approximately eightfold between

\footnotetext{
* Correspondence: chen.hao@epa.gov; tong.haiyan@epa.gov

'Oak Ridge Institute for Science and Education, Oak Ridge, TN 37830, USA ${ }^{2}$ Public Health and Integrated Toxicology Division, Center for Public Health and Environmental Assessment, U.S. Environmental Protection Agency, Chapel Hill, NC 27514, USA

Full list of author information is available at the end of the article
}

1972 and 2018; resulting in a fivefold rise in the annual area burned [163]. Southeastern Australia is a densely populated region where large-scale wildfires have led to massive life and property loss [169]. Multiple forms of vegetation in wildlands, including trees, bushes, grass, and their partially decayed form "peat", fuel these fires, and smoke emitted from the combustion of these vegetations are referred to as wildfire smoke, with alternative names including "landscape fire smoke", "wildland fire smoke", "peat fire smoke", "forest fire smoke", and "biomass smoke" [30, 75, 156]. Wildfire smoke contains many air pollutants known to be detrimental to human health, such as particulate matter (PM) and volatile organic compounds (VOCs) [4, 30]. 
Wildfires impact public health since wildfire smoke presents a source of air pollution in neighboring and even more distant populated areas [30, 85]. Epidemiological studies estimate that the global mortality burden attributable to landscape fire smoke is approximately 339,000 deaths annually [75]. Between 2008 to 2012, about 10.3 million individuals in the United States were estimated to have experienced unhealthy air quality levels (average daily fire- $\mathrm{PM}_{2.5}>35 \mu \mathrm{g} / \mathrm{m}^{3}$ ) associated with exposure to wildfire for more than 10 days [120]. Evidence also indicates an association between the longdistance transport of $\mathrm{PM}_{2.5}$ resulting from wildfire smoke and the adverse health effects in susceptible populations thousands of miles away $[84,85]$.

As a leading cause of death worldwide [69], cardiovascular disease (CVD), especially ischemic heart disease (IHD) and stroke, has been shown to associate with increased levels of air pollutants such as PM [51]. Wildfire events can cause an abrupt increase in ambient $\mathrm{PM}_{2.5}$ levels to more than $2000 \mu \mathrm{g} / \mathrm{m}^{3}$ [3, 8]. Exposure to such short-term elevations in PM levels are capable of evoking cardiac arrhythmias, worsening heart failure, and triggering atherosclerotic/ischemic cardiovascular complications, particularly in certain high-risk subpopulations [29]. Biomass smoke has also been found to be comparable to tobacco smoke as a cardiovascular comorbidity factor among patients with COPD, suggesting the need to treat diseases associated with biomass combustion similarly to those associated with tobacco use [61].

Understanding whether wildfire smoke exposure increases cardiovascular risk is of utmost importance to provide scientific evidence to better inform policymaking to protect public health, especially in the most vulnerable segments of the population. Wildfire smoke exposure has been linked to increased hospitalization and emergency department (ED) visits for respiratory symptoms, exacerbation of asthma, and chronic obstructive pulmonary disease (COPD), but the association with elevated cardiovascular risks, primarily based on epidemiological studies, is less conclusive [4, 30, 123, 124]. In recent years, a growing number of observational and experimental studies have investigated cardiovascular effects of wildfire smoke and their associated mechanisms. The observational studies include studies focusing on wildfire smoke and also on household biomass smoke that can be important sources of evidence of an association with cardiovascular risk [47]. The experimental studies using wood smoke, are more likely to capture acute pathophysiological changes associated with wood smoke exposure, compared to the observational studies that are based on healthcare data such as hospitalizations and ED visits for acute cardiovascular symptoms [138]. In this review, we will systematically examine the evidence from these studies on the association between cardiovascular health impacts and wildfire smoke (including biomass smoke and wood smoke) exposure and their possible underlying mechanisms. This review will also identify knowledge gaps and point to possible directions for future research.

\section{Literature search}

Wildfire in this review is conceptualized within the definitions of landscape fires encompassing wild and prescribed forest fires, tropical deforestation fires, peat fires, agricultural burning, and grass fires. Wildfires release approximately $2 \times 10^{12} \mathrm{~kg}$ of carbon into the atmosphere annually $[75,156]$. The main aim of this review is to examine evidence from the published peer-reviewed literature on the association between cardiovascular effects and exposure to wildfire smoke. Combustion of household biomass fuels for cooking and heating including wood, grass, and straw, which are also commonly found in wildfire scenarios, contributes to both indoor and ambient air pollution. In addition, a number of controlled human wood smoke exposure studies that are sufficiently powered to infer a causal relationship will be discussed in concert with both in vivo animal and in vitro toxicological experiments. Although the composition of household biomass smoke and experimental wood smoke is different from that of wildfire smoke, studies of biomass and experimental wood smoke provide important information that may be used to infer an association between cardiovascular effects and wildfire smoke and the associated mechanisms. Therefore, a number of household biomass smoke studies as well as clinical and experimental wood smoke studies will also be included to complement the wildfire studies in this review.

We searched peer-reviewed publications on the topic of wildfire smoke and cardiovascular health covering the period between 1980 and 2020. Terms including "forest fire smoke", "wildfire smoke", "biomass smoke", "wildland fire smoke", "peat fire smoke", "wood smoke", and "prescribed fire" have been employed interchangeably in the literature. Searches were performed using two engines, "PubMed" and "Web of Science". As shown in Fig. 1, searching "PubMed" and "Web of Science" yielded 949 and 866 results as of April 7th, 2020, respectively. After duplicate exclusion and title screening, 182 records in English language were assessed for their eligibility for further review. After excluding 31 letters or perspectives, 8 review articles, and 37 studies on coal or animal dung as combustion fuel or that did not specify the types of fuel, 108 publications were included for detailed review. These included 77 epidemiological studies which were further grouped into 48 wildfire smoke studies (Table 2 and Table S1) and 29 indoor and ambient biomass smoke studies (Table S2). Of the remaining 


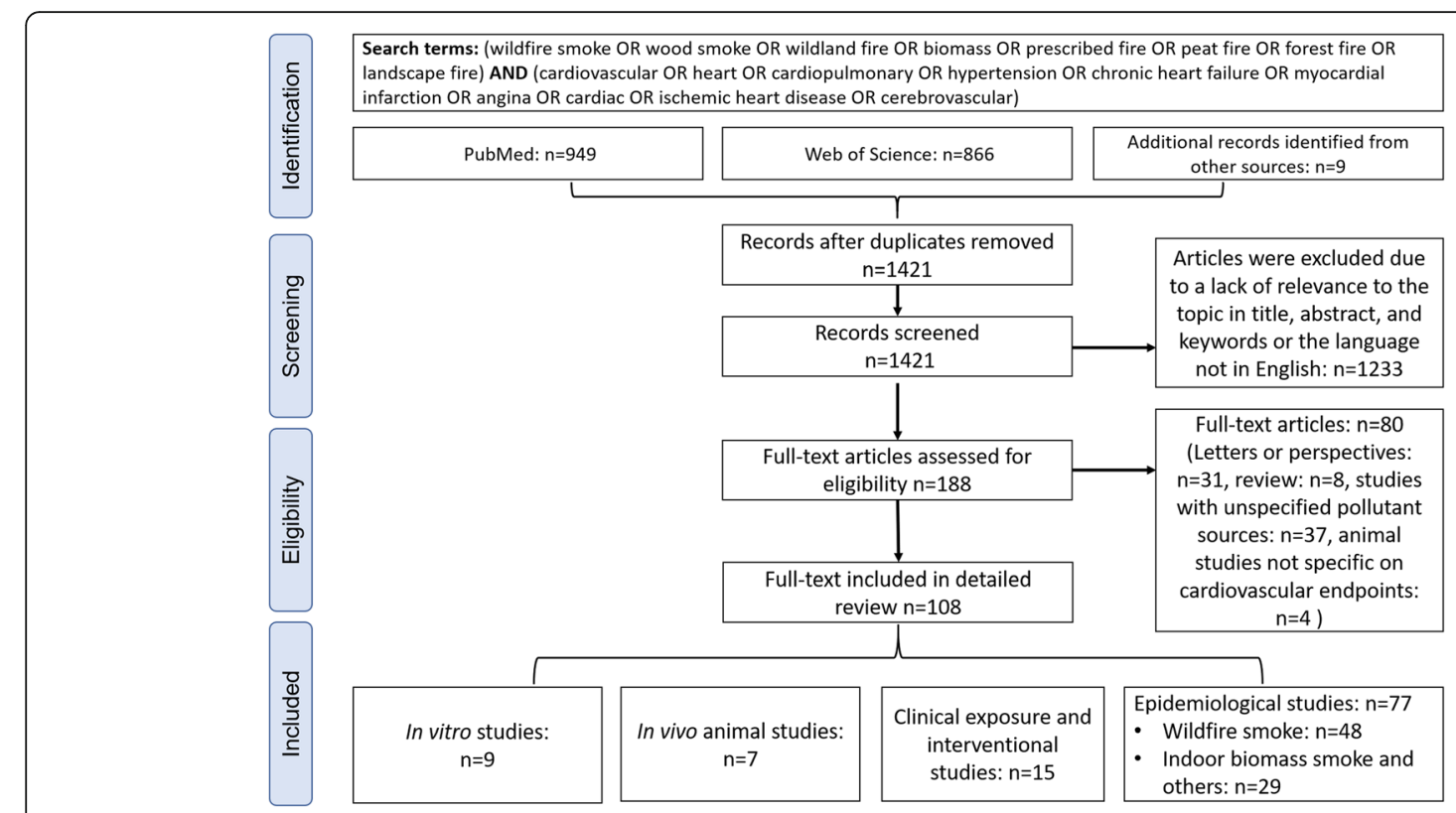

Fig. 1 Literature review flow chart

31 articles, 15 were controlled human exposure or interventional studies (Table S3), 7 were in vivo animal studies (Table S4), and 9 were in vitro studies (Table S5).

\section{Composition of wildfire smoke}

Wildfire smoke is complex physically and chemically, and its composition is determined by fuel type and combustion conditions $[30,83]$. Wildfire smoke generally consists of coarse and fine PM, VOCs (e.g., aldehydes, nalkanes), polycyclic aromatic hydrocarbons (PAHs), gases (e.g., $\mathrm{CO}, \mathrm{SO}_{2}, \mathrm{NO}, \mathrm{NO}_{2}$ ), and metals [155]. PM composition is a summation of the emitted mixture of compounds that is usually present as soot or oily substances high in elemental and organic carbon, and metallic compounds [155]. VOCs and gases are normally dispersed into the environment and they are able to react further photochemically to generate secondary organic aerosol (SOA), for example in situ ozone oxidation of alkanes in the ambient air, which can also be detrimental to human health $[60,113]$. Clinical and toxicological studies offer a detailed opportunity to examine the chemical compositions of wood smoke, a major contributor of wildfire smoke, in a controlled experimental setting. The chemical composition of wood smoke in a laboratory setting is different from that of wildfire smoke in a natural environment where vegetation characteristics, combustion conditions, weather conditions, and the geographical area burnt are factors that add complexity relative to emissions from the combustion or pyrolysis of one or two types of wood in a controlled chamber environment. As summarized from these studies in Table 1, wood smoke, independently of fuel type and combustion conditions, is characterized by the presence of PM, gases, n-alkanes, PAHs, methoxyphenol compounds, levoglucosan, and metals species.

Most epidemiological studies in this review did not provide detailed chemical profiles of the wildfire smoke studied. Instead, they employed large-scale air pollution data derived from local air quality monitoring stations or satellite imagery obtained during wildfire seasons that feature elevated levels of $\mathrm{PM}_{2.5}$ and/or $\mathrm{PM}_{10}$, with a few studies also relying on the concentrations of other index air pollutants such as $\mathrm{SO}_{2}$, oxides of nitrogen $\left(\mathrm{NO}_{\mathrm{x}}\right)$, CO, and ozone $[2,28,37,43,45,92,126]$. In all cases, wildfire events dramatically elevated ambient air pollutant levels. For example, the peak levels of $\mathrm{PM}_{2.5}$ and $\mathrm{PM}_{10}$ during wildfire days were approximately 10 times higher than those in non-fire days in Sydney, Australia [94]. Efforts have also been made specifically to address the role of organic compounds in epidemiology by using environmental markers of PAHs such as delta-C $[18,19$, $38,45,127]$. Delta-C is based on a calculation of the difference between light absorption of ultraviolet black carbon (BC), measured at $370 \mathrm{~nm}$ and $\mathrm{BC} 880 \mathrm{~nm}$ with a two-wavelength aethalometer [38], and was used for source apportionment for wood smoke [159]. Studies have employed urinary 1-hydroxypyrene (1-OHP), a metabolic biomarker of PAHs $[14,131,132]$ as an index of exposure, and found that the urinary 1-OHP levels measured in a group of Mexican women who were exposed to indoor biomass smoke can be 11 times above the mean reported for the general population [132]. In addition, measurement of levoglucosan, a sugar 
Table 1 Chemicals detected in wood smoke in laboratory studies

\begin{tabular}{|c|c|c|}
\hline $\begin{array}{l}\text { Pollutant } \\
\text { category }\end{array}$ & Chemicals found in the wood smoke & Note \\
\hline $\begin{array}{l}\text { Particulate } \\
\text { matter }\end{array}$ & $\mathrm{PM}_{1}, \mathrm{PM}_{2.5}, \mathrm{PM}_{10}$ & $\begin{array}{l}\text { The mass of PM ranges from } \\
\text { tens to thousands in } \mu \mathrm{g} / \mathrm{m}^{3} \text { a }\end{array}$ \\
\hline Gases & $\mathrm{CO}, \mathrm{NO}, \mathrm{NO}_{2}, \mathrm{SO}_{2}$ & CO: $2.7-1385 \mathrm{ppm}^{\mathrm{a}}$ \\
\hline $\begin{array}{l}\text { n-Alkane } \\
\text { compounds }\end{array}$ & $\begin{array}{l}\text { Pentadecane, Hexadecane, Octadecane, Nonadecane, Docosane, Tricosane, Tetracosane, } \\
\text { Pentacosane, Heptacosane }\end{array}$ & $\begin{array}{l}\% \text { n-Alkane in PM mass: } \\
0-0.9 \%^{a}\end{array}$ \\
\hline $\begin{array}{l}\text { Polyaromatic } \\
\text { compounds }\end{array}$ & $\begin{array}{l}\text { Phenanthrene, Anthracene, Methylphenanthrene, Methylanthracene, Fluoranthene, Pyrene, } \\
\text { Benz(a)fluorene, Benz(b)fluorene, Methylchrysene, Naphthalene, Retene, Chrysene, }\end{array}$ & $\begin{array}{l}\% \text { PAH compounds in PM } \\
\text { mass: } 0-0.5 \%^{a}\end{array}$ \\
\hline $\begin{array}{l}\text { Methoxyphenol } \\
\text { compounds }\end{array}$ & $\begin{array}{l}\text { Guaiacol, Methoxymethyl phenol, Ethylguaiacol, Eugenol, Propylguaiacol, Vanillin, Isoeugenol, } \\
\text { 3,5-Dimethoxyphenol, Syringaldehyde, Acetosyringone, Coniferyl aldehyde }\end{array}$ & $\begin{array}{l}\text { \% Methoxyphenol in PM } \\
\text { mass: } 0.1-6.5 \%{ }^{a}\end{array}$ \\
\hline Levoglucosan & Levoglucosan & $\begin{array}{l}\text { \% Levoglucosan in PM mass: } 0.9- \\
12.6 \%^{\text {a }}\end{array}$ \\
\hline $\begin{array}{l}\text { Inorganic } \\
\text { constituents }\end{array}$ & $\mathrm{Ca}, \mathrm{Cd}, \mathrm{Cr}, \mathrm{Cu}, \mathrm{K}, \mathrm{Mg}, \mathrm{Na}, \mathrm{Pb}, \mathrm{Si}, \mathrm{Zn}, \mathrm{Al}, \mathrm{Ba}, \mathrm{Fe}, \mathrm{Mn}, \mathrm{NH}_{4}^{+}, \mathrm{PO}_{4}{ }^{3-}, \mathrm{Cl}^{-}, \mathrm{NO}_{3}{ }^{-}, \mathrm{SO}_{4}{ }^{2-}$, & - \\
\hline
\end{tabular}

Note: Representative chemicals and their values were adapted and summarized from published studies $([17,57,58,83,90,100,106])$. Note: ${ }^{a}$ indicated the detected range dependent on variations in wood types (e.g. red oak, birch, eucalyptus, peat, etc) and combustion conditions (e.g., incomplete versus complete)

anhydride byproduct of pyrolysis of cellulose was utilized as a relative indicator of exposure to products of pyrolysis from burning biomass [55].

\section{Cardiovascular effects of wildfire smoke Epidemiological studies}

Wildfire events are normally transient in nature and, therefore, pose a challenge to the implementation of prospective cohort or case-control epidemiological study designs that require long-term exposure observations. A significant challenge is the lack of clear definition of the timeline that corresponds to the PM measurements, for instance, whether it represent 3-day averages, $24 \mathrm{~h}$ averages or one-hour daily peak averages. Instead, crosssectional, case crossover time-series, population-based cohort, or ecological study designs are commonly employed to assess the possible association between wildfire smoke exposure and cardiovascular risk in epidemiological studies as summarized in Table 2 and Table S1. Most of these studies have found that certain populations are at a higher risk of acute adverse cardiovascular effects due to wildfire smoke exposure.

\section{Cardiovascular morbidity}

Of the 48 wildfire epidemiological studies, 38 are on cardiovascular morbidity (Table 2 and S1), and most outcomes focus on ED visits and hospitalizations for cardiovascular symptoms and illness, for which extensive data are available from hospitals and governmental health agencies. Twenty-five of the 38 studies have reported a positive association between wildfire smoke exposure and increased healthcare needs for CVD.

Wildfire smoke exposures were categorized based on exposure time or location. Employing a time-series study design, researchers in Australia stratified continuous air pollution data into different exposure doses in order to compare the healthcare needs between non-smoky days and smoky days when either $\mathrm{PM}_{2.5}$ or $\mathrm{PM}_{10}$ concentrations exceeded $99 \%$ of the days during the entire time series. They found that increased ED visits for CVD (e.g., IHD, arrhythmias) were associated with elevated levels of $\mathrm{PM}_{10}$ and $\mathrm{PM}_{2.5}$ on smoky days [37, 76]. Lee et al. [86] demonstrated that during the 1999 forest fire near the Hoopa Valley Indian reservation in California, daily $\mathrm{PM}_{10}$ levels were significant predictors of the number of patients seeking care for circulatory and respiratory illnesses among residents of Hoopa and nearby communities. A recent study found that out-of-hospital cardiac arrest risk was significantly elevated in association with heavy smoke during wildfire events in California between 2015 to 2017 [77]. Rappold and colleagues employed a population-based cohort study design and discovered that, compared with wildfire-free counties, there was an increased number of ED visits for cardiovascular illness in counties impacted by exposure to smoke from a peat bog wildfire in North Carolina in 2008, with the association being more prominent for the elderly population [121]. Parthum et al. [114] investigated effects of another peatland fire in Virginia in 2008 and found that the fire event significantly contributed to 32 and 33 more ED visits for congestive heart failure (CHF) and cardiopulmonary symptoms respectively, compared with those on non-fire days.

Continuous air pollution data, such as ambient concentration of $\mathrm{PM}_{2.5}$ levels, were also commonly directly employed in the analyses. Similar to the North Carolina peat wildfire study [121], a $10 \mu \mathrm{g} / \mathrm{m}^{3}$ increase in $24-\mathrm{h}$ $\mathrm{PM}_{2.5}$ during peat fires was correlated with increased risk of hypertension in adults, and of all-cause cardiac outcomes in youth [149]. Haikerwal et al., reported that an interquartile range increase of $9.04 \mu \mathrm{g} / \mathrm{m}^{3}$ in $\mathrm{PM}_{2.5}$ over a 2-day moving average during the 2006-2007 
Table 2 A summary of epidemiological studies of the association between wildfire smoke exposure and cardiovascular effects

\begin{tabular}{|c|c|c|c|}
\hline Study & Exposure measurement & Endpoints & Association \\
\hline \multicolumn{4}{|l|}{ Cardiovascular morbidity } \\
\hline \multirow[t]{3}{*}{ Mott et al. [105] } & \multirow[t]{3}{*}{ Smoky vs. non-smoky periods } & Overall cardiorespiratory & $\uparrow$ \\
\hline & & $\mathrm{IHD}$ & $\rightarrow$ \\
\hline & & Circulatory disease & $\rightarrow$ \\
\hline Moore et al. [103] & Temporal comparison & All CVD & $\rightarrow$ \\
\hline \multirow[t]{2}{*}{ Johnston et al. [73] } & \multirow[t]{2}{*}{ Monitored $\mathrm{PM}_{10}$} & All CVD & $\rightarrow$ \\
\hline & & $\mathrm{IHD}$ & $\uparrow$ \\
\hline \multirow{2}{*}{$\begin{array}{l}\text { Hanigan, Johnston, } \\
\text { and Morgan [65] }\end{array}$} & \multirow[t]{2}{*}{ Modeled $\mathrm{PM}_{10}$} & All circulatory & $\rightarrow$ \\
\hline & & IHD & $\rightarrow$ \\
\hline \multirow[t]{4}{*}{ Delfino et al. [41] } & \multirow[t]{4}{*}{ Estimated $\mathrm{PM}_{2.5}$ and $\mathrm{PM}_{10}$} & All CVD & $\rightarrow$ \\
\hline & & $\mathrm{IHD}$ & $\rightarrow$ \\
\hline & & $\mathrm{HF}$ & $\rightarrow$ \\
\hline & & Other & $\rightarrow$ \\
\hline Henderson et al. [68] & Modeled $\mathrm{PM}_{10}$ & All CVD & $\rightarrow$ \\
\hline \multirow[t]{2}{*}{ Lee et al. [86] } & \multirow[t]{2}{*}{ Monitored $\mathrm{PM}_{10}$} & Circulatory & $\uparrow$ \\
\hline & & CAD & $\uparrow$ \\
\hline \multirow[t]{4}{*}{ Morgan et al. [104] } & \multirow[t]{4}{*}{ Monitored $\mathrm{PM}_{10}$} & All CVD & $\uparrow$ \\
\hline & & Cardiac & $\uparrow$ \\
\hline & & IHD & $\rightarrow$ \\
\hline & & Stroke & $\rightarrow$ \\
\hline \multirow{2}{*}{$\begin{array}{l}\text { Schranz, Castillo, and Vilke } \\
\text { [137] }\end{array}$} & \multirow[t]{2}{*}{ Temporal comparison } & CAD & $\rightarrow$ \\
\hline & & CHD & $\rightarrow$ \\
\hline Henderson et al. [67] & Modeled $\mathrm{PM}_{10}$ & All CVD & $\rightarrow$ \\
\hline \multirow[t]{3}{*}{ Rappold et al. [121] } & \multirow[t]{3}{*}{ Temporal and spatial comparison } & All CVD & $\rightarrow$ \\
\hline & & Ml & $\rightarrow$ \\
\hline & & HF & $\uparrow$ \\
\hline Crabbe [37] & $\begin{array}{l}\text { Monitored PM } \mathrm{PM}_{10} \text {, coarse PM, fine PM, black } \\
\text { carbon }\end{array}$ & CVD & $\uparrow$ \\
\hline Rappold et al. [118] & Modeled PM 2.5 & Congestive HF & $\uparrow$ \\
\hline Hejl et al. [66] & Temporal comparison & Blood cardiovascular markers & $\uparrow$ \\
\hline \multirow[t]{4}{*}{ Martin et al. [94] } & \multirow[t]{4}{*}{ Smoky vs. non-smoky periods } & Arrythmia & $\rightarrow$ \\
\hline & & Cardiac failure & $\rightarrow$ \\
\hline & & Cerebrovascular disease & $\rightarrow$ \\
\hline & & $\mathrm{IHD}$ & $\rightarrow$ \\
\hline Gaughan et al. [55] & Urinary levoglucosan level & Mean augmentation index \% & $\uparrow$ \\
\hline Rappold et al. [119] & Modeled $\mathrm{PM}_{2.5}$ & Congestive HF & $\uparrow$ \\
\hline \multirow[t]{5}{*}{ Johnston et al. [76] } & \multirow[t]{5}{*}{ Smoky vs. non-smoky periods } & All CVD & $\rightarrow$ \\
\hline & & $\mathrm{IHD}$ & $\uparrow$ \\
\hline & & Arrythmias & $\uparrow$ \\
\hline & & Cerebrovascular disease & $\rightarrow$ \\
\hline & & Cardiac failure & $\uparrow$ \\
\hline
\end{tabular}


Table 2 A summary of epidemiological studies of the association between wildfire smoke exposure and cardiovascular effects (Continued)

\begin{tabular}{|c|c|c|c|}
\hline Study & Exposure measurement & Endpoints & Association \\
\hline \multirow[t]{5}{*}{ Le et al. [85] } & \multirow[t]{5}{*}{ Temporal comparison, monitored $\mathrm{PM}_{2.5}$} & All CVD & $\uparrow$ \\
\hline & & $\mathrm{IHD}$ & $\uparrow$ \\
\hline & & HF & $\uparrow$ \\
\hline & & Cerebrovascular disease & $\rightarrow$ \\
\hline & & Heart rate disturbances & $\uparrow$ \\
\hline Dennekamp et al. [43] & Monitored $\mathrm{PM}_{2.5}, \mathrm{PM}_{10}, \mathrm{CO}, \mathrm{O}_{3}, \mathrm{SO}_{2}, \mathrm{NO}_{2}$ & Cardiac arrest & $\uparrow$ \\
\hline \multirow[t]{4}{*}{ Haikerwal et al. [64] } & \multirow[t]{4}{*}{ Modeled $\mathrm{PM}_{2.5}$} & Cardiac arrest & $\uparrow$ \\
\hline & & IHD & $\uparrow$ \\
\hline & & Acute Ml & $\rightarrow$ \\
\hline & & Angina & $\rightarrow$ \\
\hline \multirow[t]{5}{*}{ Resnick et al. [126] } & \multirow[t]{5}{*}{ Temporal comparison } & All CVD & $\uparrow$ \\
\hline & & $\mathrm{IHD}$ & $\rightarrow$ \\
\hline & & Hypertension & $\rightarrow$ \\
\hline & & Cerebrovascular disease & $\uparrow$ \\
\hline & & $\begin{array}{l}\text { Disease of veins, lymphatics, and circulatory } \\
\text { system }\end{array}$ & $\uparrow$ \\
\hline \multirow[t]{4}{*}{ Alman et al. [8] } & \multirow[t]{4}{*}{ Monitored $\mathrm{PM}_{2.5}$} & CVD & $\rightarrow$ \\
\hline & & Acute Ml & $\rightarrow$ \\
\hline & & $\mathrm{IHD}$ & $\rightarrow$ \\
\hline & & Dysrhythmia & $\rightarrow$ \\
\hline \multirow[t]{5}{*}{ Ostro et al. [111] } & \multirow[t]{5}{*}{ Modeled source-apportionment $\mathrm{PM}_{2.5}$} & All CVD & $\rightarrow$ \\
\hline & & $\mathrm{IHD}$ & $\rightarrow$ \\
\hline & & Ml & $\rightarrow$ \\
\hline & & Dysrhythmia & $\uparrow$ \\
\hline & & HF & $\rightarrow$ \\
\hline \multirow[t]{4}{*}{ Reid, Jerrett, et al. [123, 124] } & \multirow[t]{4}{*}{ Temporal comparison and modeled $\mathrm{PM}_{2.5}$} & All CVD & $\rightarrow$ \\
\hline & & $\mathrm{IHD}$ & $\rightarrow$ \\
\hline & & CHD & $\rightarrow$ \\
\hline & & Congestive HF & $\rightarrow$ \\
\hline \multirow[t]{4}{*}{ Tinling et al. [149] } & \multirow[t]{4}{*}{ Modeled $\mathrm{PM}_{2.5}$} & All-cause cardiac conditions & $\uparrow$ \\
\hline & & Cardiac dysrhythmia & $\uparrow$ \\
\hline & & HF & $\rightarrow$ \\
\hline & & Hypertension & $\uparrow$ \\
\hline $\begin{array}{l}\text { Yao, Eyamie, and } \\
\text { Henderson 2016) [165] }\end{array}$ & Smoky vs. non-smoky periods & CVD & $\uparrow$ \\
\hline \multirow[t]{6}{*}{ Gan et al. [53] } & \multirow[t]{6}{*}{ Modeled PM 2.5} & CVD & $\uparrow$ \\
\hline & & Arrhythmia & $\rightarrow$ \\
\hline & & Cerebrovascular disease & $\uparrow$ \\
\hline & & HF & $\rightarrow$ \\
\hline & & $\mathrm{IHD}$ & $\rightarrow$ \\
\hline & & Ml & $\rightarrow$ \\
\hline \multirow[t]{2}{*}{ Garcia-Olivé et al. [54] } & \multirow[t]{2}{*}{ Burnt area \% (spatial comparison) } & Acute MI & $\rightarrow$ \\
\hline & & HF & $\rightarrow$ \\
\hline Liu et al. [88] & Temporal comparison and modeled $\mathrm{PM}_{2.5}$ & CVD & $\rightarrow$ \\
\hline
\end{tabular}


Table 2 A summary of epidemiological studies of the association between wildfire smoke exposure and cardiovascular effects (Continued)

\begin{tabular}{|c|c|c|c|}
\hline Study & Exposure measurement & Endpoints & Association \\
\hline \multirow{2}{*}{$\begin{array}{l}\text { Parthum, Pindilli, and } \\
\text { Hogan [114] }\end{array}$} & \multirow[t]{2}{*}{ Modeled $\mathrm{PM}_{2.5}$} & $\mathrm{CHF}$ & $\uparrow$ \\
\hline & & Cardiopulmonary disease & $\uparrow$ \\
\hline \multirow[t]{3}{*}{ Salimi et al. [133] } & \multirow[t]{3}{*}{ Monitored $\mathrm{PM}_{2.5}$} & Cardiac arrest & $\uparrow$ \\
\hline & & Stroke & $\uparrow$ \\
\hline & & Other heart problems & $\uparrow$ \\
\hline Weichenthal et al. [160] & Monitored $\mathrm{PM}_{2.5}$ & $\mathrm{Ml}$ & $\uparrow$ \\
\hline \multirow[t]{7}{*}{ Wettstein et al. [161] } & \multirow[t]{7}{*}{ Smoke density } & All CVD & $\uparrow$ \\
\hline & & Hypertension & $\uparrow$ \\
\hline & & IHD & $\rightarrow$ \\
\hline & & $\mathrm{Ml}$ & $\uparrow$ \\
\hline & & Dysrhythmia & $\uparrow$ \\
\hline & & $\mathrm{HF}$ & $\uparrow$ \\
\hline & & Ischemic stroke & $\uparrow$ \\
\hline Abdo et al. [2] & Modeled $\mathrm{PM}_{2.5}$ & Gestational hypertension & $\uparrow$ \\
\hline Deflorio-Barker et al. [40] & Smoke vs non-smoke days & Cardiopulmonary & $\rightarrow$ \\
\hline \multirow[t]{6}{*}{ Stowell et al. [147] } & \multirow[t]{6}{*}{ Modeled $\mathrm{PM}_{2.5}$} & Acute Ml & $\rightarrow$ \\
\hline & & Congestive HF & $\rightarrow$ \\
\hline & & Dysrhythmia & $\rightarrow$ \\
\hline & & $\| H D$ & $\rightarrow$ \\
\hline & & Cerebrovascular disease & $\rightarrow$ \\
\hline & & CVD & $\rightarrow$ \\
\hline Jones et al. [77] & Modeled $\mathrm{PM}_{2.5}$ & Cardiac arrest & $\uparrow$ \\
\hline \multicolumn{4}{|l|}{ Cardiovascular mortality } \\
\hline Vedal and Dutton [157] & Monitored $\mathrm{PM}_{2.5}$ and $\mathrm{PM}_{10}$ & Cardiorespiratory & $\rightarrow$ \\
\hline $\begin{array}{l}\text { Analitis, Georgiadis, } \\
\text { and Katsouyanni [10] }\end{array}$ & Areas burnt (spatial comparison) & CVD & $\uparrow$ \\
\hline Marlier et al. [92] & Modeled $\mathrm{PM}_{2.5}$ and $\mathrm{O}_{3}$ & CVD & $\uparrow$ \\
\hline \multirow{3}{*}{$\begin{array}{l}\text { Nunes, Ignotti, and } \\
\text { Hacon [109] }\end{array}$} & \multirow[t]{3}{*}{ Modeled $\mathrm{PM}_{2.5}$} & CVD & $\uparrow$ \\
\hline & & Acute Ml & $\uparrow$ \\
\hline & & Cerebrovascular disease & $\rightarrow$ \\
\hline \multirow[t]{2}{*}{ Shaposhnikov et al. [143] } & \multirow[t]{2}{*}{ Monitored $\mathrm{PM}_{10}$} & IHD & $\uparrow$ \\
\hline & & Cerebrovascular disease & $\uparrow$ \\
\hline Linares et al. [87] & $\begin{array}{l}\text { Temporal comparison, monitored } \mathrm{PM}_{2.5} \text { and } \\
\mathrm{PM}_{10}\end{array}$ & Circulatory disease & $\rightarrow$ \\
\hline Faustini et al. [48] & Smoky vs. non-smoky days & CVD & $\uparrow$ \\
\hline Kollanus et al. [84] & Monitored $\mathrm{PM}_{2.5}$ & CVD & $\uparrow$ \\
\hline Navarro et al. [107] & Modeled $\mathrm{PM}_{2.5}$ & CVD & $\uparrow$ \\
\hline $\begin{array}{l}\text { Uda, Hein, and } \\
\text { Atmoko [153] }\end{array}$ & Modeled $\mathrm{PM}_{2.5}$ & CVD & $\uparrow$ \\
\hline
\end{tabular}

wildfire season in Victoria, Australia, was significantly associated with a $6.98 \%$ increase in risk of out-ofhospital cardiac arrests, with the strongest associations observed among men and older adults, and was also associated with an increased risk for IHD-related ED visits (2.07\%) and hospitalizations (1.86\%), particularly among women and the elderly [64]. In addition to $\mathrm{PM}_{2.5}$, the same group found that the ambient levels of 
$\mathrm{PM}_{10}$ and $\mathrm{CO}$ were also correlated with a 48-h lag to an elevated incidence of increased out-of-hospital cardiac arrests among men during the wildfire events, although $\mathrm{PM}_{2.5}$ was still the main contributor of these effects [43]. A larger scale study in the Greater Sydney Metropolitan area from 2004 to 2015 showed similar results, specifically that a $10 \mu \mathrm{g} / \mathrm{m}^{3}$ increase in $\mathrm{PM}_{2.5}$ resulting from the wildfire smoke was positively associated with the number of same-day emergency ambulance dispatches responding to calls for cardiac arrest, stroke, and chest pain [133].

In contrast, 13 of the 38 studies reported null associations between cardiovascular healthcare needs and wildfire smoke exposure. During a 2003 forest fire event in British Columbia Canada, despite significant increases in physician visits for respiratory complaints, the physician visits for CVD were not significantly increased by forest fire smoke containing a peak of $200 \mu \mathrm{g} / \mathrm{m}^{3} \mathrm{PM}_{10}$ and $250 \mu \mathrm{g} / \mathrm{m}^{3} \mathrm{PM}_{2.5}$ [103]. Similar to the British Columbia study, Henderson and colleagues employed a population-based cohort methodology and multiple exposure assessment metrics, including tapered element oscillating microbalance measurements, a CALPUFF dispersion model, and a SMOKE exposure metric. Despite more novel methods, they reached the same conclusion that no significant association were observed between $\mathrm{PM}_{10}$ exposure and cardiovascular hospital admissions $[67,68]$. Null cardiovascular results were also reported in the USA $[8,40,41,88,123,124$, 137, 147] and in Australia [94, 104], in spite of the presence of strong links to the incidence of respiratory diseases [8, 40, 41, 104, 137, 147].

\section{Cardiovascular mortality}

Among the 10 epidemiological studies investigating the association between exposure to wildfire smoke and cardiovascular mortality, eight found a positive association. Using satellite-derived estimates and atmospheric modeling for exposure categorization, wildfire contributed to 200 days per year in which the World Health Organization's 24-h $\mathrm{PM}_{2.5}$ interim air quality target was exceeded in Southeast Asia between 1997 and 2006, leading to an estimated $2 \%$ annual increase in adult cardiovascular mortality [92]. Similarly, smoky days with $\mathrm{PM}_{10}$ higher than $8 \mu \mathrm{g} / \mathrm{m}^{3}$ based on satellite data, were significantly related to increased cardiovascular mortality, during forest fire episodes in several Mediterranean cities in 20032010 [48]. A recent study from Indonesia found that peatland fire smoke contributed to an annual average of $26 \mu \mathrm{g} / \mathrm{m}^{3} \mathrm{PM}_{2.5}$ per year, and was associated with excess mortality due to respiratory or cardiovascular causes [153]. In addition to PM, other meteorological conditions, such as high temperature, were determined to be co-contributors to the association between increased cardiovascular mortality and wildfire events [143].

As with the morbidity studies discussed above, null associations have also been reported in a couple of cardiovascular mortality studies. One study showed that the daily cardiorespiratory mortality was not associated with same-day wildfire smoke containing peak $\mathrm{PM}_{10}$ and $\mathrm{PM}_{2.5}$ levels of 372 and $200 \mu \mathrm{g} / \mathrm{m}^{3}$, respectively [157]. Another study also reported no significant associations between increased $\mathrm{PM}_{10}$ levels during biomass fires and cardiovascular mortality, even though there was a significant finding for respiratory mortality among people who were $\geq 75$ years old [87]. Some authors argue that the mortality impact of short-term increases in PM due to wildfire would not be expected to be limited to 1 day but show a lag several days later [157], and this could explain the lack of a relationship between wildfire smoke exposures and cardiovascular mortality.

\section{Occupational exposure to wildfire smoke}

Firefighters are a special group of workers who are likely to be exposed to high levels of air pollutants during wildfire events [110, 125]. Hejl et al. [66] showed that firefighters exposed to up to $1306 \mu \mathrm{g} / \mathrm{m}^{3} \mathrm{PM}_{2.5}$ during firefighting had increased serum markers of inflammation (IL-8) and altered vascular function (ICAM1, VCAM1). Another study showed that elevated mean augmentation index, an indicator of arterial stiffness, was linked to urinary levoglucosan levels among wildfire firefighters [55]. These pathophysiological changes may lead to higher risks of adverse cardiovascular outcomes among firefighters due to exposure to wildfire smoke. Navarro found that firefighters who worked 49 days per year were exposed to a mean concentration of $\mathrm{PM}_{4}$ at $510 \mu \mathrm{g} / \mathrm{m}^{3}$ during wildland firefighting activities. They estimated that the increased PM exposure was associated with increased risk of lung cancer as well as CVDrelated mortality [107].

\section{Indoor and ambient biomass smoke}

While the focus of this review is on wildfire smoke, there are 29 studies (Table S2) examining the health impacts of indoor or ambient exposure to biomass smoke from household fuel combustion for cooking or heating using wood, grass, or straw. Using a cohort study design, researchers identified differences among cardiovascular outcomes between cohorts exposed to biomass smoke and control groups. Compared with those using cleaner fuels, biomass use in Peruvian households was associated with significantly higher levels of indoor $\mathrm{PM}_{2.5}$ concentrations, which were, in turn, associated with increased carotid intima media thickness, elevated prevalence of carotid plaques, and higher systolic blood pressure (SBP) [112]. Similarly, the use of biomass fuel for cooking was 
associated with elevations in SBP, diastolic blood pressure (DBP), and mean arterial pressure, with a stronger association observed among older populations in China [21, 42]. In addition to $\mathrm{PM}_{2.5}$, one study in Western Kenya showed that smoke from the incomplete combustion of locally acquired wood contained high levels of household $\mathrm{CO}$, which was a driver of an association with heart abnormalities detected by echocardiography [5]. A cross-sectional study in Turkey reported that long-term exposure to indoor biomass smoke was associated with systolic and diastolic biventricular dysfunction, as well as increased pulmonary artery systolic pressure [80]. However, some studies have found no significant association between increased cardiovascular risk and indoor exposure to biomass smoke [33, 101, 102, 142]. Indoor biomass combustion contributes to ambient air pollution, which has also been linked to increased incidence of cardiovascular outcomes. A $10 \mu \mathrm{g} / \mathrm{m}^{3}$ increase in ambient $\mathrm{PM}_{2.5}$ levels due to wood combustion for winter heating in Tasmania, Australia was significantly associated with an increased rate of hospitalization for heart failure [72]. Domestic wood combustion for heating in Central Launceston, Australia was associated with increased levels of ambient $\mathrm{PM}_{10}$ and increased cardiovascular mortality; the effects were mitigated by intervention to reduce wood smoke production [74]. It is important to note that smoke emitted from household combustion of biomass is not equal to wildfire smoke; therefore, caution is advised when interpreting results from these biomass smoke studies.

\section{Vulnerable populations}

It is known that certain subpopulations are more susceptible to health impacts of exposure to air pollution, including children, the elderly, the obese, pregnant women, people with low socio-economic status (SES), and those with underlying lung and heart diseases $[79,96]$. These subpopulations are also more susceptible to wildfire smoke exposure, especially the elderly, pregnant women, and those with lower SES.

The elderly are more likely to seek healthcare (i.e. ED visits, hospitalizations) due to cardiovascular issues, such as IHD, CHF, cardiac arrest and acute myocardial infarction (MI), during wildfire season [64, 76, 77, 105, 118]. Many more studies are in agreement with this finding, with small variations of the age at which these effects are evident. Exposure to high $\mathrm{PM}_{2.5}$ levels were strongly associated with increased rates of acute MI among people $>75$ years old [109], and with increases in ED visits for cardiovascular dysfunction (e.g. IHD, dysrhythmia, heart failure, stroke and MI) among people $>65$ years old [126, 161]. In addition, meteorological factors such as low ambient temperature positively modified the association between increases in 3-day average $\mathrm{PM}_{2.5}$ levels and increased risk of MI among the elderly ( $\geq 65$ years old) during biomass fire periods [160]. Interestingly, a few studies revealed the possibility that wildfire emissions can impact the health of more remote elderly populations after long-distance transport of the particles. The 2002 Quebec forest fires in Canada significantly increased average $\mathrm{PM}_{2.5}$ levels during hazy days to $53 \mu \mathrm{g} / \mathrm{m}^{3}$ from $21.5 \mu \mathrm{g} / \mathrm{m}^{3}$ on clear days in the United States. Compared with the clear days, the rate of hospitalizations for both respiratory and cardiovascular illness were increased during the hazy days among the elderly [85]. Similar evidence was found in a Finnish study which reported that a $10 \mu \mathrm{g} / \mathrm{m}^{3}$ increase in $\mathrm{PM}_{2.5}$, attributed to a long-range transport from vegetation fires, was associated with all-cardiovascular mortality especially among population $>65$ years old [84].

Pregnant women are also susceptible to wildfire smoke exposure. Abdo and colleagues examined the impact of wildfire smoke on hypertension during pregnancy and reported that a $1 \mu \mathrm{g} / \mathrm{m}^{3}$ increase in $\mathrm{PM}_{2.5}$ exposure to wildfire smoke over the full gestation or during the 1st and 2nd trimester was positively associated with gestational hypertension, in addition to adverse effects on premature birth and decreased birth weight in newborns [2]. Using delta-C as an environmental marker for wood combustion, Assibey-Mensah and colleagues first discovered that each $0.52 \mu \mathrm{g} / \mathrm{m}^{3}$ increase in delta-C concentration during the 7th and 8th gestational month was associated with an elevated risk of hypertensive disorders of pregnancy [18]. They also report that exposure to wood smoke-sourced fine PM was positively associated with an increased risk of early onset of preeclampsia during pregnancy [19].

Health disparity was another risk factor that may render certain subpopulations more susceptible to wildfire smoke-associated cardiovascular effects. A study showed that indigenous people in Darwin, Australia were more likely to be admitted to the hospital for IHD and respiratory illnesses during vegetation fire season when there were significantly increased levels of $\mathrm{PM}_{10}[65,73]$. Jones and colleagues indicated that low SES may increase the risk of out-of-hospital cardiac arrest due to wildfire smoke exposure during wildfire events in California [77]. Rappold and colleagues compared the ED visits due to wildfire smoke between top- and bottom-ranked counties in North Carolina stratified by socioeconomic factor and found that increased ED visits for asthma and CHF were significantly higher in the low SES counties, 85 and $124 \%$ respectively, per $100 \mu \mathrm{g} / \mathrm{m}^{3}$ increase in $\mathrm{PM}_{2.5}$ [118].

Cigarette smoking may increase the susceptibility to adverse health impacts of wildfire smoke among smokers. Cigarette smoking is an established risk factor for cardiovascular disease [9] and there is a positive 
interaction between cigarette smoking and $\mathrm{PM}_{2.5}$ for cardiovascular mortality [152]. It is likely that smoking or history of cigarette smoking may increase wildfire smoke-induced cardiovascular morbidity; however, to our knowledge, no studies have specifically investigated such an interaction. Nonetheless, many studies do consider smoking and smoking history as a co-variate on the association between wildfire smoke exposure and cardiovascular diseases $[18,118]$.

\section{Limitations of epidemiological studies of the effects of wildfire smoke}

As shown in Table 3, a number of studies showed positive association between wildfire smoke exposure and cardiovascular endpoints while several presented null associations. The inconsistency of the findings might result from differences in study design, endpoint choices, case count, and exposure assessment.

Some epidemiological studies employed an integrated approach to include large-scale healthcare and mortality data that may not be representative of the whole population. Some studies noted that null findings for cardiovascular effects were partly attributed to the low cardiovascular case counts, leading to wide confidence intervals, relative to respiratory case counts [8]. Outcomes based on healthcare needs for cardiovascular issues are likely to limit the investigations to certain susceptible subpopulations, while omitting healthier subgroups who may have developed small but significant pathophysiological effects, involving oxidative stress and inflammation.

Epidemiological studies are also prone to exposure misclassification due to their dependence on the use of exposure data from air quality monitoring stations or satellite images [85]. The broad approach applies exposure data based on smoky days, smoky area, scale of burnt forests, or air pollutant levels for the entire region [48, 54, 118], but does not consider individual-specific differences such as activity level, time spent indoors versus outdoors, and wind direction changes that may drastically affect the actual concentration of wildfire smoke. Total suspended particle levels from a study on biomass smoke derived from agricultural combustion of sugar cane, for example, may not specify particulate size information that is toxicologically relevant [16]. It has been shown that the amount of wood combustion in a city

Table 3 Characteristics of the studies reviewed

\begin{tabular}{|c|c|c|c|c|c|}
\hline Study type & $\begin{array}{l}\text { Number } \\
\text { of } \\
\text { studies }\end{array}$ & $\begin{array}{l}\text { Number of } \\
\text { studies } \\
\text { showing } \\
\text { positive } \\
\text { association }\end{array}$ & Major findings & Strength & Limitation \\
\hline $\begin{array}{l}\text { Epidemiological } \\
\text { studies on } \\
\text { wildfire smoke }\end{array}$ & 48 & 33 & $\begin{array}{l}\text { Wildfire smoke exposure (most } \\
\text { using } \mathrm{PM}_{2.5} \text { or } \mathrm{PM}_{10} \text { as exposure } \\
\text { metric) is associated with } \\
\text { increased morbidity and mortality } \\
\text { of IHD, HF, CAD, CHD, and } \\
\text { arrhythmia }\end{array}$ & $\begin{array}{l}\text { Direct investigation on the } \\
\text { cardiovascular effects of wildfire } \\
\text { smoke exposure; relatively } \\
\text { straightforward availability of } \\
\text { hospitalization records and air } \\
\text { quality (mainly PM) data }\end{array}$ & $\begin{array}{l}\text { Exposure misclassification; limited } \\
\text { causal inference; difficult to } \\
\text { capture subclinical cardiovascular } \\
\text { changes; failure to consider the } \\
\text { effects of gases }\left(\mathrm{O}_{3}, \mathrm{NO}_{2} \text {, etc) and }\right. \\
\text { VOCs from wildfire smoke }\end{array}$ \\
\hline $\begin{array}{l}\text { Epidemiological } \\
\text { studies on } \\
\text { household } \\
\text { biomass smoke }\end{array}$ & 29 & 26 & $\begin{array}{l}\text { Indoor biomass smoke exposure } \\
\text { is associated with increased blood } \\
\text { pressure, vascular dysfunction, } \\
\text { circulating vascular markers, and } \\
\text { cardiovascular morbidity and } \\
\text { mortality }\end{array}$ & $\begin{array}{l}\text { Study sites and length are not } \\
\text { restricted to wildfire events; } \\
\text { straightforward follow-up with } \\
\text { subjects using household fuels; } \\
\text { applicability of interventions; can } \\
\text { study subclinical endpoints }\end{array}$ & $\begin{array}{l}\text { Household biomass smoke is not } \\
\text { equal to wildfire smoke; not ideal } \\
\text { for causal inference, cannot } \\
\text { account for real-world wildfire } \\
\text { events }\end{array}$ \\
\hline $\begin{array}{l}\text { Intervention / } \\
\text { controlled } \\
\text { human } \\
\text { exposure } \\
\text { studies }\end{array}$ & 15 & 11 & $\begin{array}{l}\text { There are significant changes in } \\
\text { vascular function, blood pressure, } \\
\text { HRV, circulating cardiovascular } \\
\text { and inflammatory markers }\end{array}$ & $\begin{array}{l}\text { Controlled exposure and } \\
\text { environmental conditions; } \\
\text { potential for causal inference; } \\
\text { detailed smoke characterization; } \\
\text { randomization and cross-over } \\
\text { design }\end{array}$ & $\begin{array}{l}\text { Wood smoke does not equal } \\
\text { wildfire smoke; cannot account for } \\
\text { other environmental conditions in } \\
\text { the real world wildfire events; } \\
\text { exposure time is relatively short }\end{array}$ \\
\hline $\begin{array}{l}\text { In vivo animal } \\
\text { studies }\end{array}$ & 7 & 6 & $\begin{array}{l}\text { At different extent, wood /peat } \\
\text { smoke condensate cause } \\
\text { cardiovascular dysfunction, and } \\
\text { increase inflammatory and } \\
\text { cardiovascular injury markers }\end{array}$ & $\begin{array}{l}\text { Detailed wood smoke } \\
\text { characterization; controlled dose } \\
\text { and exposure duration; sound } \\
\text { model to examine cardiovascular } \\
\text { function; sound for mechanistic } \\
\text { studies }\end{array}$ & $\begin{array}{l}\text { Wood smoke does not equal } \\
\text { wildfire smoke; difficult to } \\
\text { generalize the information to } \\
\text { human exposure; intratracheal } \\
\text { aspiration as exposure method in } \\
\text { some studies is different from } \\
\text { inhalation }\end{array}$ \\
\hline In vitro studies & 9 & 8 & $\begin{array}{l}\text { Wood smoke extract can induce } \\
\text { cytotoxicity, oxidative stress and } \\
\text { altered levels of inflammatory and } \\
\text { vascular markers }\end{array}$ & $\begin{array}{l}\text { Detailed wood smoke } \\
\text { characterization; controlled dose } \\
\text { and exposure duration; sound for } \\
\text { mechanistic studies }\end{array}$ & $\begin{array}{l}\text { Wood smoke does not equal } \\
\text { wildfire smoke; difficult to } \\
\text { generalize the information to } \\
\text { human exposure }\end{array}$ \\
\hline
\end{tabular}


does not necessarily guarantee that the measured $\mathrm{PM}_{10}$ levels are representative of wood smoke exposure [44, 135].

Exposure misclassification can also be due to data quality factors or variations in the statistical methods used to process the data. Several studies surveyed in this review failed to distinguish between PM from wildfire smoke or background urban PM, while a few studies subtracted the background levels [10, 84, 85, 111]. In addition, fire intensity does not necessarily correspond to smoke levels and thus is not a sound metric for smoke exposure assessment [10]. The $\mathrm{PM}_{2.5}$ results based on modeled air pollution level seem to vary from model to model. Yao et al. [165] found that even though close in values, modeled $\mathrm{PM}_{2.5}$ concentrations, but not the measured levels, were associated with increased physician visits for cardiovascular disease on smoky days during the forest fire seasons of 2003 through 2010 in British Columbia, Canada. Gan and colleagues estimated $\mathrm{PM}_{2.5}$ concentrations based on both satellite and in situ data using three distinct methods: the Weather Research and Forecasting with Chemistry chemical-weather model, the Kriged interpolation of $\mathrm{PM}_{2.5}$ data from of in situ surface monitors, and a geographically weighted regression. The three models overall generated consistent $\mathrm{PM}_{2.5}$ exposure levels, but there were some significant differences among specific locations where the models were used, resulting in varying conclusions regarding the associations [53].

A majority (42 out of 48) of the wildfire smoke epidemiological studies reviewed (Table S1) utilized PM as an exposure metric for wildfire smoke in a variety of timelines and size fractions, and only 6 studies examined measured levels of gases (e.g. $\mathrm{O}_{3}, \mathrm{CO}$ ) and volatile organic compounds (e.g. levoglucosan). Null findings between exposure to wildfire smoke and cardiovascular health effects may be due to the lack of accounting for gases, VOCs, PAHs and SOA, as well as cumulative exposure and co-exposures. While monitoring gaseous components from wildfire smoke can be challenging, some studies did propose indirect methodology including the environmental markers such as delta- $C$ and metabolic markers such as 1-OHP for exposure assessment of PAHs from wildfire smoke [12, 13, 45]. However, such methods may not best represent exposure to organic compounds due to the low correlation between these markers and the actual air pollutant levels. For example, in one study the Pearson correlation factor between the delta-C levels and ambient $\mathrm{PM}_{2.5}$ levels was only $R=0.26$ [18].

Some other limitations are identified in epidemiological studies that may lead to bias when interpreting results from these studies. For example, one study did not adequately account for important covariates such as temperature, humidity, and time trends [126]. Another study may have low power to detect an effect as it claims a positive finding with only a correlation between 2-day exposure and 2-day mortality data [157]. In addition, the choice of groups compared is questionable in this study, where frequency of pulmonary hypertension among women exposed to biomass smoke was higher than that among men who were cigarette smokers [141]. All the limitations discussed here may contribute the inconclusive results of a positive association between wildfire smoke exposure and cardiovascular effects in epidemiological studies.

\section{Controlled clinical exposure studies}

Controlled clinical exposure studies complement the cardiovascular mortality and morbidity observations in epidemiology as they offer a chance to examine the associated pathophysiological changes. As shown in Table 3 and S3, wood smoke used in clinical and experimental studies in laboratory settings may not represent wildfire smoke entirely. In a clinical chamber setting, it is possible to maintain a relatively consistent wood smoke concentration, coupled with controllable environmental conditions such as temperature, humidity, and barometric pressure. In addition, chamber studies also allow researchers to characterize the chemical composition of the wood smoke (Table 1) and potentially investigate their roles in the cardiovascular effects. Low or moderate exercise can be introduced in the study protocols to increase the ventilatory rate to simulate physical activity in the vicinity of a wildland fire. The randomization and crossover design utilized in the chamber studies significantly reduce the influence of confounding covariates and are statistically efficient [25]. These considerations in clinical exposure studies significantly avoid exposure misclassification and provide much higher confidence in the causal inference of observed associations between wood smoke exposure and cardiovascular effects. These studies often purposely focus on the combustion of a single type or source of combustion material (e.g., red oak from a single tree or neighboring trees harvested from a single location) in order to minimize variability in the exposures from subject to subject.

Most clinical wood smoke exposure studies conducted to date have investigated pulmonary function, respiratory inflammation and systemic inflammatory responses, while about a dozen included cardiovascular endpoints or markers related to vascular pathophysiology. Commonly investigated cardiovascular endpoints include heart rate variability (HRV), vascular function, blood pressure, circulating endothelial adhesion molecules (e.g. ICAM1, VCAM1 and p-selectin), and coagulation proteins (vWF, tPA, and D-dimer). HRV is a reflection of the autonomic nervous system control on the heart and 
is quantified in the time domain with measurements of the time interval between consecutive heartbeats, and in the frequency domain, which measures the absolute or relative amount of signal energy within component bands [154]. An optimal level of HRV is associated with cardiac health; decreased HRV among healthy individuals is reported as a risk factor of cardiovascular morbidity and mortality [151]. Controlled chamber exposure to air pollutants, such as concentrated ambient fine and ultrafine PM, can significantly decrease HRV among middle-aged healthy subjects [150]. In one study, 14 subjects underwent a 3-h controlled exposure to a mean $\mathrm{PM}_{1}$ concentration at $314 \mu \mathrm{g} / \mathrm{m}^{3}$ of wood smoke generated through pyrolysis of birch wood with intermittent moderate exercise (an average minute ventilation of 20 $\mathrm{L} / \mathrm{min} / \mathrm{m}^{2}$ body surface area (BSA)). The authors found that HRV markers in the time domain, including standard deviation of successive $\mathrm{NN}$ intervals $(\mathrm{SDNN})$, rootmean square of successive $\mathrm{NN}$ interval differences (RMSSD), and the proportion of NN50 divided by the total number of NN (R-R) intervals (pNN50), were significantly decreased $1-\mathrm{h}$ after wood smoke exposure compared to filtered air [154]. In another study, 43 subjects participated in various training exercises that included activities to extinguish fires fueled by either wood alone or by wood and household materials (mattress). They found that firefighting activity was associated with decreased HRV and microvascular function measured as reactive hyperemia index [14]. On the other hand, a few studies have reported no significant changes in HRV following exposure to red oak wood smoke $(485 \pm 84 \mu \mathrm{g} /$ $\left.\mathrm{m}^{3}\right)[57,58]$, or to Danish beech wood smoke $(13,222$, and $385 \mu \mathrm{g} / \mathrm{m}^{3}$ ) [24].

Several studies investigated changes in vascular function and blood pressure post exposure to wood smoke. Exposure to birch wood smoke significantly increased heart rate and central arterial stiffness, though not blood pressure [154]. After 1-h exposure to wood smoke measured as $\mathrm{PM}_{1}$ at about $1000 \mu \mathrm{g} /$ $\mathrm{m}^{3}$ of birch wood smoke with intermittent exercise (average minute ventilation target $20 \mathrm{~L} / \mathrm{min} / \mathrm{m}^{2} \mathrm{BSA}$ ), 16 male firefighters showed significantly increased blood carboxyhemoglobin and increased vasodilatory response to bradykinin infusion compared with controls exposed to clean air, but no change in arterial pressure or pulse wave velocity [71]. The concentrations of the endothelial adhesion molecules ICAM1 and VCAM1 showed changes in the blood of healthy adults following a 3-h resting exposure to wood smoke corresponding to start-up and burn-out phases [144]. A few other studies failed to find any positive effects on vascular endpoints, but did report that blood markers related to vascular pathophysiology, such as coagulation factors, lipid peroxidation and oxidative stress, were significantly increased after wood smoke exposure [20,50].

In a clinical study that included six different cookstoves that represent different combustion conditions, 48 subjects each underwent 2-h wood smoke exposures over six sessions at $\mathrm{PM}_{2.5}$ doses ranging from 0 to $500 \mu \mathrm{g} / \mathrm{m}^{3}$. Overall, the results showed that mean SBP, but not DBP, was 2 to $3 \mathrm{mmHg}$ higher for all but one stove emission. All cookstove treatments also marginally increased pulse wave velocity and central augmentation index after $24 \mathrm{~h}$ compared to control. These results raised concerns that even low level $\mathrm{PM}_{2.5}$ from the most efficient cookstove can pose adverse cardiovascular effects $[49,158]$. Similar reductions of cardiovascular effects associated with use of efficient energy usage to reduce indoor biomass smoke levels were also found in other observational studies $[6,34,164]$.

\section{In vivo animal studies}

As with clinical exposure studies, wood smoke used in the animal studies surveyed was derived from the combustion of one or two types of wood. The exposure methodology was either inhalation by animals breathing spontaneously in a small chamber, or intratracheal instillation of an extract prepared from condensed wood smoke. As summarized in Table S4, several studies have shown that exposure to wood smoke leads to increased cardiovascular risk in animals. Kim and colleagues established an in vivo model wherein female CD-1 mice were exposed to $100 \mu \mathrm{g}$ peat smoke condensate from different combustion stages (smoldering vs. near-extinguished) through oropharyngeal aspiration. The mice exposed to the smoke produced during the smoldering-stage showed significantly decreased cardiac function and increased post-ischemic cardiac death in an experimentally induced ischemia model [82]. Another study demonstrated that Sprague-Dawley (SD) rats exposed to peat fire smoke extracts through oropharyngeal aspiration showed significantly higher end-systolic volume and pulmonary artery blood flow acceleration/ejection time ratios. Though minimal immune cell changes were observed in the bronchoalveolar lavage fluid (BALF), high doses of peat smoke PM extract (350 $\mu$ g per animal) led to altered regulation of ventricular ejection and filling volumes, affecting blood flow in the pulmonary circulation [148]. In a study investigating the cardiometabolic responses to a high fat diet, rats exposed to peat fire smoke for $1 \mathrm{~h}$ showed increases in serum high-density lipoprotein (HDL) and total cholesterol, as well as increased isovolumic heart relaxation time after high fat food challenge, compared to values seen in control rats exposed to filtered air [93].

On the other hand, Reed and colleagues did not find any significant changes in cardiovascular markers among 
different animal strains (F344 rats, SHR rats, A/J mice, and C57BL/6 mice) after subchronic exposure to mixed oak wood smoke [122]. The animals in this study were whole-body exposed to different concentrations of wood smoke particulates $\left(30,100,300\right.$, and $\left.1000 \mu \mathrm{g} / \mathrm{m}^{3}\right)$ for 6 h per day, 7 days a week for either 1 week or 6 months. The investigators evaluated cardiovascular function using electrocardiograms. No consistent changes were apparent under the wood smoke exposure conditions of this study, although increases in platelet numbers and decreases in blood urea nitrogen and serum alanine aminotransferase were reported [122]. Animal studies have also shown that the toxicity of wood smoke depends on the wood type as well as the combustion conditions, with wood smoke from either smoldering or flaming oak showing weaker effects relative to smoke produced by the burning of a few other wood types [81, 83, 140]. More details on how composition of wood smoke will affect its toxicity will be discussed in the next section.

\section{Mechanisms of cardiovascular impacts of wildfire smoke}

As summarized in Table 3, in vivo animal and in vitro studies may often be challenging to interpret in a clinical context, as exposure dose and duration may be difficult to compare with real world conditions impacting public health. However, these studies provide insight into underlying pathophysiological mechanisms. In this section, we will focus on evidence from the literature including controlled human exposure studies, in vivo animal studies and in vitro studies to discuss the possible mechanisms of wildfire smoke induced cardiovascular effects.

Several hypotheses have been proposed regarding the biological mechanisms underlying the health effects of air pollution. Among them are three principal pathways supported by evidence from epidemiological, clinical and toxicological studies [108, 146]. First, air pollutants can directly interact with neural receptors in the respiratory system and activate the autonomic nervous system, which has an impact on the heart rhythm and blood pressure. Second, pulmonary exposure to air pollutants produces oxidative stress and local and systemic inflammation, leading to lipid peroxidation, increased platelet activation and thrombosis, inflammation of vascular endothelia, and increased vasomotor tone. Lastly, small molecules of air pollutants, such as ultrafine PM and gases, may translocate through alveolar membranes and cause cardiovascular effects, including endothelial activation and injury $[30,99,116]$. There is limited research conducted directly on the mechanisms of cardiovascular effects caused by wildfire smoke, but after reviewing direct and indirect evidence from the literature, we postulate possible mechanistic pathways of cardiovascular effects induced by exposure to wildfire smoke based on these three notions (Fig. 2).

\section{Autonomic nervous system imbalance}

As discussed earlier, wood smoke exposure under controlled conditions can significantly decrease HRV (i.e., SDNN, RMSSD, pNN50), a commonly examined endpoint of autonomic nervous system function [14, 154]. Inhalation of air pollutants, such as wildfire smoke, triggers autonomic reflexes in pulmonary receptors, baroreceptors, and chemoreceptors, leading to altered functional outcomes in the cardiovascular system [116].

Vagal sensory nerves and neural receptors in the respiratory system function to maintain normal respiratory physiology and pulmonary defense, and are sensitive to various environmental irritants [95]. These respiratory receptors include those found on unmyelinated $C$ fibers (e.g., TRPA1, TRPV1, and J receptors), rapidly adapting pulmonary receptors (RAR), and slowly adapting pulmonary receptors (SAR) $[116,162]$. Although not tested in wildfire smoke, studies of individual components present in wildfire smoke have shown potential to activate these receptors. For example, inhalation of high levels of ozone or volatile aldehydes can cause cardiovascular and pulmonary injury through activation of the TRPA1 receptor in humans and animals [28, 35, 62].

Activated sensory nerves send signals to the central nervous system, leading to modulation of the baroreceptor reflex that controls blood pressure and normal cardiovascular function [36]. In addition, these sensory nerves signal to the carotid body chemoreceptors located at the bifurcation of the carotid artery to maintain homeostasis of $\mathrm{O}_{2}, \mathrm{CO}_{2}, \mathrm{pH}$, temperature and blood pressure [91]. Multiple studies have reported significant changes in blood pressure following exposure to wildfire smoke or wood smoke in humans in epidemiological and clinical studies [21, 32, 49, 167]. Wildfire smoke components, including $\mathrm{PM}$, ozone, and $\mathrm{SO}_{2}$, have been shown to significantly decrease baroreflex sensitivity or affect the activity of chemoreceptors in the carotid body $[116,130]$. Nevertheless, more research is needed to directly investigate the role of autonomic nerves in the control of the cardiovascular effects of wildfire smoke exposure.

\section{Oxidative stress and systemic inflammation}

Oxidative stress is believed to be a key mechanism by which exposure to air pollution causes cardiovascular morbidity and mortality [97]. Components of wildfire smoke particles such as metals, are known to induce oxidative stress through redox and non-redox cycling mechanisms $[57-59,134]$.

Cultured human pulmonary artery endothelial cells exposed to $40 \mu \mathrm{g} / \mathrm{ml}$ of wood smoke condensate for $1-4 \mathrm{~h}$ 


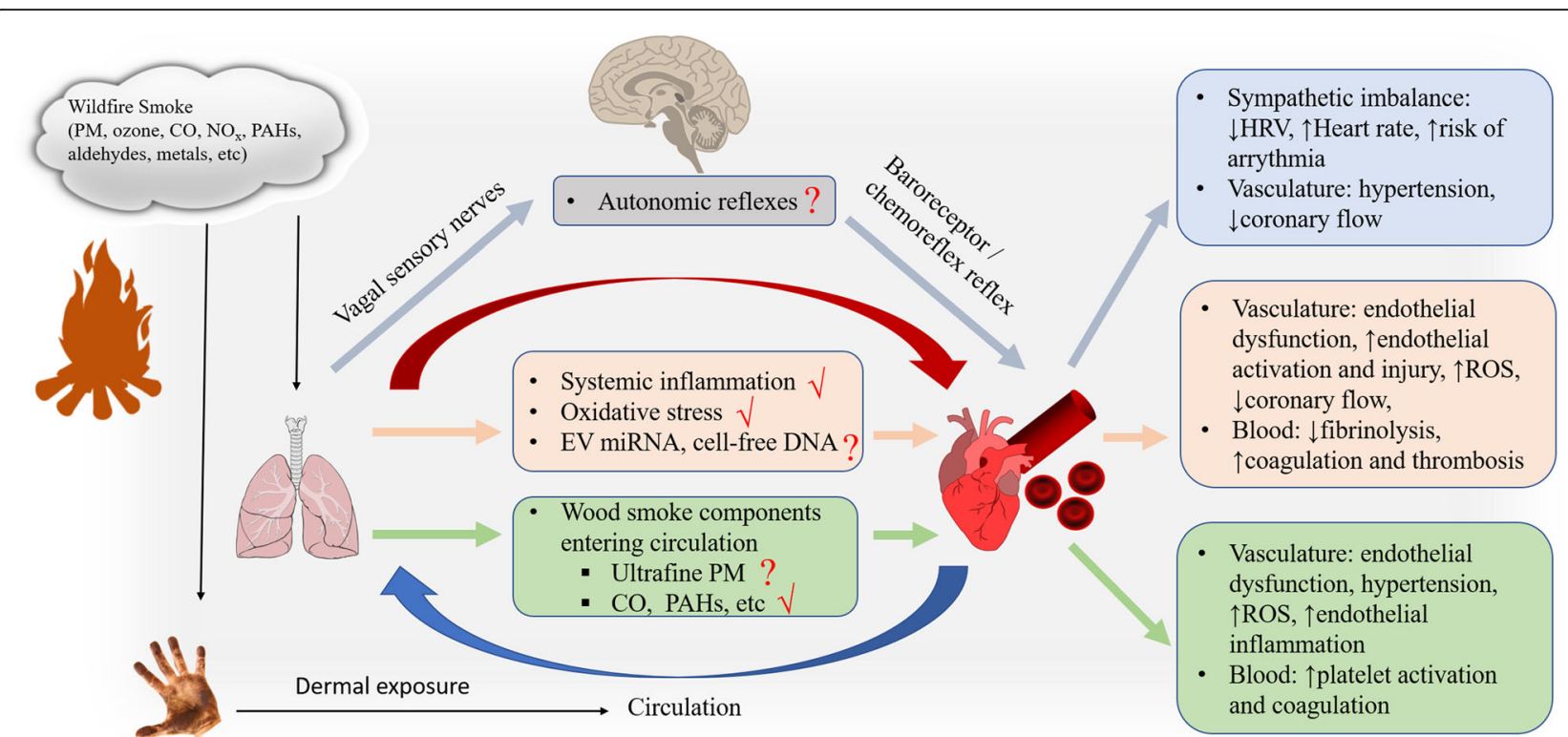

Fig. 2 Schematic pathway showing proposed pathophysiological mechanisms of cardiovascular effects induced by wildfire smoke exposure. Wildfire smoke contains PM, gases, PAHs, and VOCs, etc. These components may affect the cardiovascular system through inhalational route, with a contribution from dermal exposure. Wildfire smoke can cause cardiovascular effects through three possible pathways: activation of autonomic reflex, oxidative stress and systemic inflammation, and direct interaction with the vasculature. Abbreviations: BP: blood pressure, CO: carbon monoxide, EV: extracellular vesicle, HRV: heart rate variability, miRNA: microRNAs, $\mathrm{NO}_{\mathrm{x}}$ : oxides of nitrogen, PAHs: polycyclic aromatic hydrocarbons, PM: particulate matter, ROS: reactive oxygen species

showed increased production of reactive oxygen species (ROS), loss of mitochondrial membrane potential, increased expression of the mitochondrial apoptosis regulator $\mathrm{Bcl}-2$ associated $\mathrm{X}$ protein (BAX), DNA fragmentation, and increased mRNA expression of superoxide dismutase 1 (SOD1) and heme oxygenase 1 (HMOX1) [89]. The antioxidant $n$-acetylcysteine was shown to reverse the oxidative stress state and restore depleted intracellular glutathione levels following wood smoke exposure [89]. Wood smoke particles from smoldering red oak also induced significant increases in ROS detected using the non-specific sensor 2',7' -dichlorofluorescein diacetate [57, 58]. Though Miousse et al. did not find any significant changes in ROS following biomass smoke exposure, mRNA expression of catalase and HMOX1 was significantly increased at 24 or $72 \mathrm{~h}$ compared to controls in an in vitro study [100].

Wood smoke-induced oxidative stress can cause a disruption of the cell cycle and cellular apoptosis. In RAW264.7 cells, birch wood smoke extract suspended in cell culture media at $15-300 \mu \mathrm{g} / \mathrm{ml}$ decreased cellular metabolism and increased the number of cells entering the subG1 phase of the cell cycle after 24-h exposure [106]. Similarly, after 40-h exposure to $40 \mu \mathrm{g} / \mathrm{cm}^{2}$ of wood smoke extract, THP-1 cells entered S/G2 phase of the cell cycle, indicating decreased proliferation [23]. Studies have also shown evidence of cytotoxicity from exposure to wood smoke by using lactate dehydrogenase (LDH) release assay $[57,58,100,106]$ or MTT assay [168], although the positive results were not present in all studies partly due to different wood type, cell line, and doses and exposure duration.

Inhaled particulates elicit inflammatory responses in the lung, and a sufficient particle dose, reactivity, or lack of clearance may lead to a "spill-over" of inflammatory responses into the blood causing systemic inflammation $[139,146]$. Clinical wood smoke exposure studies have consistently found significantly elevated blood markers of inflammation, including interleukin 1 beta (IL-1 $\beta$ ), IL6, IL-8, C-C motif chemokine ligand 2 (CCL2), clara cell protein $16(\mathrm{CC} 16)$, and tumor necrosis factor $\alpha$ (TNF $\alpha)$ [50, 57, 58, 63, 144, 145]. In vivo animal studies also offered insights on wood smoke exposure induced inflammatory responses locally and systemically. Exposure of $\mathrm{BALB} / \mathrm{c}$ mice to an organic wood smoke extract from emissions derived from spruce combustion significantly increased inflammatory responses (COX-2, MPO) in both respiratory and cardiovascular systems [46]. Serum collected from C57BL/6 mice exposed to oak wood smoke $\left(\mathrm{PM}_{2.5}\right.$ at $\left.380 \mu \mathrm{g} / \mathrm{m}^{3}\right)$ for $24 \mathrm{~h}$ was able to induce pro-inflammatory responses (IL-6 and CXCL1), and elevated expression of adhesion molecules (VCAM1 and ICAM1) in murine endothelial cells [15]. Wood smoke produced from smoldering fire generated higher levels of aerosolized endotoxin and potently induced cytokine levels, neutrophil influx, and intracellular ROS 
production in mouse lavage fluid relative to emissions produced at the near-extinguishing stage [82]. In vitro toxicological investigations have yielded similarly consistent inflammatory responses caused by exposure to wood smoke extract across different experimental cell lines, exposure time, and doses $[23,57,58,90,106]$.

Recent research has pointed to extracellular vesicle (EV) microRNAs (miRNA) released by exposed cells into the circulation, which may facilitate cell-to-cell communications and play a role in air-pollution induced cardiovascular effects. Studies have shown that exposure to $\mathrm{PM}_{2.5}$ or ozone, two important components of wildfire smoke, was associated with an altered profile of miRNA targets such as miR-126, miR-19b, miR-150, miR-155, miR-191, and let-7a in human circulation [31, 128]. Many of these miRNA targets were associated with cardiovascular pathophysiology [129]. In terms of wildfire smoke, Ruiz-Vera and colleagues found that the expression of plasma miR-126 and miR-155 was significantly higher in women exposed to wood smoke compared to those using liquid petroleum gas (LPG), a cleaner form of fuel. In addition, there was a significant association between miR-126 and miR-155 expression levels and urinary 1-OHP concentrations, an indicator of $\mathrm{PAH}$ exposure [131].

\section{Distinguishing between the effects of particles and absorbed volatile components}

Studies show that UFPs with a mean aerodynamic diameter $<100 \mathrm{~nm}$ may translocate into the blood circulation through the alveolar-capillary barrier, reaching the heart and peripheral blood vessels [52, 136]. A more recent study found that nano-sized particles could be detected in surgical specimens of the carotid artery of animals and in the blood and urine of healthy human volunteers following acute inhalation of the particles [98]. Ultrafine wildfire smoke PM might have the same potential to cross the epithelial barrier to enter the pulmonary circulation.

In addition, when wildfire smoke particles deposit in the alveolar region, the majority of their available PAHload may rapidly detach from the particles, and transfer across the epithelial barrier and diffuse into the bloodstream in an unmetabolized state [56, 70]. Interestingly, an in vitro study has shown that wood smoke-induced proinflammatory responses and cytotoxicity were mainly determined by the organic fraction, rather than the washed particulates [23]. In addition to the particulates, gaseous components of wood smoke including $\mathrm{SO}_{2}$, ammonia, $\mathrm{NO}_{x}$, and $\mathrm{CO}$ were found to be important contributors to the pro-atherosclerotic vascular response to air pollution exposure in mice [140]. A series of studies testing the chemical components of wood smoke generated from different kinds of biomass (red oak, pocosin peat, ponderosa pine needles, lodgepole pine, eucalyptus) at different combustion stage (smoldering versus flaming) showed different acute pulmonary toxicity and mutagenicity in mice $[81,83]$.

\section{Research needs}

A growing number of studies have implicated exposure to wildfire smoke as a risk factor for CVD. However, significant knowledge gaps regarding the association remain. Future epidemiological studies would benefit from improved exposure assessments and the implementation of more sensitive indicators of cardiovascular dysfunction. Similarly, the development of new methodologies could allow researchers to acquire individualized wildfire smoke exposure assessment, capturing more accurate exposure data [26, 27]. In addition to index air pollutants, future studies should also consider the impact of VOCs, which may be an important driver of wildfire smoke effects. Besides large-scale morbidity and mortality data, the identification of sensitive biomarkers should warrant information on the early onset of injury and on the underlying mechanisms of cardiovascular effects induced by wildfire smoke exposure. Since the direct evidence is lacking, more research is needed on how wildfire smoke exposure induces cardiovascular effects through the autonomic nervous system and directly impacts the vasculature. Novel mechanistic concepts including the role played by circulating miRNAs and cellfree DNA in the circulation on endothelial activation and injury should also be investigated.

There is also a geographical disparity in terms of the number of studies representing different regions. Among the wildlife smoke epidemiological studies presented in Table S1, 29 studies are from North America, 1 from South America, 9 from Australia, 3 from Southeast Asia, and 6 from Europe. However, there were no studies from Africa where Savanna fires are common and intensification of wildfire frequency and scale is projected for the future [11, 39]. More wildfire smoke studies should be carried out in these underrepresented regions where the public health system is more vulnerable, especially under the circumstances of global warming and increased wildland-urban interface.

Data should serve as the scientific backbone for policymaking in public health issues. As wildfire events are likely to occur more frequently in the foreseeable future, scientific efforts should be directing attention to the possible interventional approaches to reduce wildfire smoke induced health effects. Physical methods such as HEPAequipped air purifiers, have showed promise in reducing exposure to wildfire smoke or wood smoke, leading to reduced inflammation and improved vascular function $[7,78]$. A wildfire smoke forecast that triggers interventions to reduce personal exposure at lower $\mathrm{PM}_{2.5}$ 
threshold could be beneficial to reduce respiratory and cardiovascular health burdens [119]. In addition, comprehensive public health measures, such as Rule 4901, to reduce wood smoke exposure have been shown to lead to reductions in cardiovascular cases and IHD cases among those 65 years and older [166]. More research on the effectiveness of these strategies and applicability at a larger population scale is warranted to generate more robust data for informed public health decisions.

\section{Conclusion}

This review finds that wildfire smoke contributes to high levels of air pollutants, including coarse and fine $\mathrm{PM}$, gases, PAHs and VOCs, during wildfire events. Exposure to these pollutants, with most evidence derived from studies of wildfire smoke PM, is a risk factor for adverse cardiovascular effects, especially among susceptible populations, including the elderly, pregnant women, and those with low SES. The young and healthy may also develop biological responses including systemic inflammation and vascular activation. The limited understanding between exposure to the gaseous components of wildfire smoke and the cardiovascular effects warrants more research. We have also discussed the importance of more accurate exposure assessment and measurement of more sensitive cardiovascular endpoints in future epidemiological studies. Clinical and toxicological research have highlighted several possible mechanisms of wildfire smoke-induced cardiovascular effects including systemic inflammation and oxidative stress, autonomic nervous system imbalance, release of EV mediators into the circulation, and direct interaction of translocated smoke components into the circulation. As large-scale wildfire events will likely occur more frequently in the future, more research is needed to understand and intervene in the cardiovascular effects of wildfire. With science-guided policy decisions, we may diminish the adverse impacts of wildfires through reducing exposure levels, mitigating toxicity, and protecting the most vulnerable.

\section{Supplementary Information}

The online version contains supplementary material available at https://doi. org/10.1186/s12989-020-00394-8.

Additional file 1: Supplemental Table 1. Summary of epidemiological studies on wildfire smoke exposure and cardiovascular effects. Supplemental Table 2. Summary of studies on indoor and ambient biomass smoke exposure and cardiovascular effects. Supplemental Table 3. Summary of intervention and controlled human exposure studies of wood smoke exposure and cardiovascular effects.

Supplemental Table 4. Summary of in vivo animal studies on wood smoke exposure and cardiovascular effects. Supplemental Table $\mathbf{5}$. Summary of in vitro studies on wood smoke exposure and biological effects related to cardiovascular system.

\section{Abbreviations}

BALF: Bronchial alveolar fluid; BAX: BCl-2-associated X protein; BC: Black carbon; BSA: Body surface area; $C C L 2$ : C-C motif chemokine ligand 2; CC16: Clara cell protein 16; CHF: Congestive heart failure; CO: Carbon monoxide; COPD: Chronic obstructive pulmonary disease; COX2: Cyclooxygenase-2; CVD: Cardiovascular disease; CXCL1: C-X-C motif chemokine ligand 1; DBP: Diastolic blood pressure; ED: Emergency department; EV: Extracellular vesicles; HDL: High-density lipoprotein; HMOX1: Heme oxygenase 1; HRV: Heart rate variability; ICAM1: Intercellular Adhesion Molecule 1; IL: Interleukin; IHD: Ischemic heart disease; LDH: Lactate Dehydrogenase; LPG: Liquid petroleum gas; MI: Myocardial infarction; MIP-2: Macrophage inflammatory protein 2; miRNA: MicroRNA; MMP9: Matrix metallopeptidase 9; MPO: Myeloperoxidase; NAC: Nacetylcysteine; $\mathrm{NO}$ : Nitric oxide; $\mathrm{NO}_{2}$ : Nitrogen dioxide; PAHs: Polycyclic aromatic hydrocarbons; PM: Particulate matter; pNN50: Proportion of NN50 divided by the total number of NN (R-R) intervals; RAR: Rapidly adapting pulmonary receptors; RMSSD: Root-mean square of successive NN interval differences; ROS: Reactive oxygen species; SAR: Slowly adapting pulmonary receptors; SBP: Systolic blood pressure; SDNN: Standard deviation of successive NN intervals; SES: Socio-economic status; $\mathrm{SO}_{2}$ : Sulfur dioxide; SOA: Secondary organic aerosol; SOD: Superoxide dismutase; TNFa: Tumor necrosis factor a; tPA: Tissue plasminogen activator; TRPA1: Transient receptor potential ankyrin 1; TRPV1: Transient receptor potential vanilloid 1; UFPs: Ultrafine particles (< $100 \mathrm{~nm}$ diameter); VCAM1: Vascular Cell Adhesion Molecule 1; VOCs: Volatile organic compounds; VWF: Von Willebrand factor; 1-OHP: 1-Hydroxypyrene

\section{Acknowledgements}

The authors would like to thank Drs. Andrew Ghio and Miyuki Breen for their suggestions to improve the manuscript.

\section{Disclaimer}

The research described in this article has been reviewed by the Center for Public Health and Environmental Assessment, U.S. EPA, and approved for publication. The contents of this article should not be construed to represent Agency policy nor does mention of trade names or commercial products constitute endorsement or recommendation for use.

\section{Authors' contributions}

$\mathrm{HC}, \mathrm{JMS}$, and $\mathrm{HT}$ conceived the idea. $\mathrm{HC}$ conducted the literature search and summary. $\mathrm{HC}, J M S, H T$, and PAB contributed to the writing and editing of the manuscript. All authors read and approved the final manuscript.

\section{Funding}

The U.S. Environmental Protection Agency Intramural Research Program supported this research.

Availability of data and materials

All data reviewed and described is either included in this manuscript or available online in the relevant publications.

Ethics approval and consent to participate

Not applicable.

Consent for publication

Not applicable.

Competing interests

The authors declare that they have no competing interests.

\section{Author details}

'Oak Ridge Institute for Science and Education, Oak Ridge, TN 37830, USA.

${ }^{2}$ Public Health and Integrated Toxicology Division, Center for Public Health and Environmental Assessment, U.S. Environmental Protection Agency,

Chapel Hill, NC 27514, USA. ${ }^{3}$ Center for Environmental Medicine, Asthma and Lung Biology, University of North Carolina at Chapel Hill, Chapel Hill, NC 27514, USA. 
Received: 19 August 2020 Accepted: 17 December 2020 Published online: 07 January 2021

\section{References}

1. Abatzoglou JT, Williams AP. Impact of anthropogenic climate change on wildfire across western US forests. Proc Natl Acad Sci U S A. 2016;113(42): $11770-5$.

2. Abdo M, Ward I, O'Dell K, Ford B, Pierce JR, Fischer EV, Crooks JL. Impact of wildfire smoke on adverse pregnancy outcomes in Colorado, 2007-2015. Int J Environ Res Public Health. 2019;16(19):3720.

3. Adetona O, Dunn K, Hall DB, Achtemeier G, Stock A, Naeher LP. Personal $\mathrm{PM}(2.5)$ exposure among wildland firefighters working at prescribed forest burns in southeastern United States. J Occup Environ Hyg. 2011;8(8):503-11.

4. Adetona O, Reinhardt TE, Domitrovich J, Broyles G, Adetona AM, Kleinman MT, Ottmar RD, Naeher LP. Review of the health effects of wildland fire smoke on wildland firefighters and the public. Inhal Toxicol. 2016;28(3): 95-139.

5. Agarwal A, Kirwa K, Eliot MN, Alenezi F, Menya D, Mitter SS, Velazquez EJ, Vedanthan R, Wellenius GA, Bloomfield GS. Household air pollution is associated with altered cardiac function among women in Kenya. Am J Respir Crit Care Med. 2018;197(7):958-61.

6. Alexander D, Larson T, Bolton S, Vedal S. Systolic blood pressure changes in indigenous Bolivian women associated with an improved cookstove intervention. Air Qua Atmosphere Health. 2015;8(1):47-53.

7. Allen RW, Carlsten C, Karlen B, Leckie S, van Eeden S, Vedal S, Wong I, Brauer M. An air filter intervention study of endothelial function among healthy adults in a Woodsmoke-impacted community. Am J Respir Crit Care Med. 2011;183(9):1222-30.

8. Alman BL, Pfister G, Hao H, Stowell J, Hu X, Liu Y, Strickland MJ. The association of wildfire smoke with respiratory and cardiovascular emergency department visits in Colorado in 2012: a case crossover study. Environ Health. 2016;15(1):64

9. Ambrose JA, Barua RS. The pathophysiology of cigarette smoking and cardiovascular disease: an update. J Am Coll Cardiol. 2004;43(10):1731-7.

10. Analitis A, Georgiadis I, Katsouyanni K. Forest fires are associated with elevated mortality in a dense urban setting. Occup Environ Med. 2012;69(3): 158-62.

11. Andela N, van der Werf GR. Recent trends in African fires driven by cropland expansion and El Niño to La Niña transition. Nat Clim Chang. 2014;4(9): 791-5.

12. Andersen MHG, Saber AT, Clausen PA, Pedersen JE, Lohr M, Kermanizadeh A, Loft S, Ebbehoj N, Hansen AM, Pedersen PB, Koponen IK, Norskov EC, Moller $P$, Vogel U. Association between polycyclic aromatic hydrocarbon exposure and peripheral blood mononuclear cell DNA damage in human volunteers during fire extinction exercises. Mutagenesis. 2018a;33(1):105-15.

13. Andersen MHG, Saber AT, Pedersen JE, Pedersen PB, Clausen PA, Lohr M, Kermanizadeh A, Loft S, Ebbehoj NE, Hansen AM, Kalevi Koponen I, Norskov EC, Vogel U, Moller P. Assessment of polycyclic aromatic hydrocarbon exposure, lung function, systemic inflammation, and genotoxicity in peripheral blood mononuclear cells from firefighters before and after a work shift. Environ Mol Mutagen. 2018b;59(6):539-48.

14. Andersen MHG, Saber AT, Pedersen PB, Loft S, Hansen AM, Koponen IK, Pedersen JE, Ebbehoj N, Norskov EC, Clausen PA, Garde AH, Vogel U, Moller $P$. Cardiovascular health effects following exposure of human volunteers during fire extinction exercises. Environ Health. 2017;16:96.

15. Aragon MJ, Chrobak I, Brower J, Roldan L, Fredenburgh LE, McDonald JD, Campen MJ. Inflammatory and vasoactive effects of serum following inhalation of varied complex mixtures. Cardiovasc Toxicol. 2016;16(2): 163-71.

16. Arbex MA, Saldiva PH, Pereira LA, Braga AL. Impact of outdoor biomass air pollution on hypertension hospital admissions. J Epidemiol Community Health. 2010;64(7):573-9.

17. Arif AT, Maschowski C, Garra P, Garcia-Kaufer M, Petithory T, Trouve G, Dieterlen A, Mersch-Sundermann V, Khanaqa P, Nazarenko I, Gminski R, Giere R. Cytotoxic and genotoxic responses of human lung cells to combustion smoke particles of Miscanthus straw, softwood and beech wood chips. Atmos Environ. 2017;163:138-54.

18. Assibey-Mensah V, Glantz JC, Hopke PK, Jusko TA, Thevenet-Morrison K, Chalupa D, Rich DQ. Ambient wintertime particulate air pollution and hypertensive disorders of pregnancy in Monroe County, New York. Environ Res. 2019;168:25-31.
19. Assibey-Mensah V, Glantz JC, Hopke PK, Jusko TA, Thevenet-Morrison K, Chalupa D, Rich DQ. Wintertime wood smoke, traffic particle pollution, and preeclampsia. Hypertension. 2020;75(3):851-8.

20. Barregard L, Sallsten G, Gustafson P, Andersson L, Johansson L, Basu S, Stigendal L. Experimental exposure to wood-smoke particles in healthy humans: effects on markers of inflammation, coagulation, and lipid peroxidation. Inhal Toxicol. 2006;18(11):845-53.

21. Baumgartner J, Schauer JJ, Ezzati M, Lu L, Cheng C, Patz JA, Bautista LE. Indoor air pollution and blood pressure in adult women living in rural China. Environ Health Perspect. 2011;119(10):1390-5.

22. Bernstein DN, Mahowald NM, Hess PGM, Tilmes S, Hamilton D, Connelly DS, Krasnoff R. 2017-2018 North America wildfires and their impact on air quality and climate; 2019.

23. Bolling AK, Totlandsdal Al, Sallsten G, Braun A, Westerholm R, Bergvall C, Boman J, Dahlman HJ, Sehlstedt M, Cassee F, Sandstrom T, Schwarze PE, Herseth II. Wood smoke particles from different combustion phases induce similar pro-inflammatory effects in a co-culture of monocyte and pneumocyte cell lines. Part Fibre Toxicol. 2012;9:45.

24. Bonlokke JH, Riddervold IS, Gronborg TK, Skogstrand K, Hougaard DM, Barregard L, Sigsgaard T. Systemic effects of wood smoke in a short-term experimental exposure study of atopic volunteers. J Occup Environ Med. 2014;56(2):177-83.

25. Bose M, Aloke AD. Optimal Crossover Designs, Optimal crossover designs; 2008.

26. Breen MS, Long TC, Schultz BD, Williams RW, Richmond-Bryant J, Breen M, Langstaff JE, Devlin RB, Schneider A, Burke JM, Batterman SA, Meng QY. Air pollution exposure model for individuals (EMI) in health studies: evaluation for ambient PM2.5 in Central North Carolina. Environ Sci Technol. 2015; 49(24):14184-94.

27. Breen M, Chang SY, Breen M, Xu Y, Isakov V, Arunachalam S, Carraway MS, Devlin R. Fine-scale modeling of individual exposures to ambient PM2.5, EC, $\mathrm{NOx}$, and CO for the coronary artery disease and environmental exposure (CADEE) study. Atmosphere. 2020;11(1):65

28. Brey SJ, Fischer EV. Smoke in the City: how often and where does smoke impact summertime ozone in the United States? Environ Sci Technol. 2016; 50(3):1288-94

29. Brook RD, Rajagopalan S, Pope CA 3rd, Brook JR, Bhatnagar A, Diez-Roux AV Holguin F, Hong Y, Luepker RV, Mittleman MA, Peters A, Siscovick D, Smith SC Jr, Whitsel L, Kaufman JD, Epidemiology American Heart Association Council on, Council on the Kidney in Cardiovascular Disease Prevention, Physical Activity Council on Nutrition, and Metabolism. Particulate matter air pollution and cardiovascular disease: An update to the scientific statement from the American Heart Association. Circulation. 2010;121(21):2331-78.

30. Cascio WE. Wildland fire smoke and human health. Sci Total Environ. 2018; 624:586-95.

31. Chen $H, X u Y$, Rappold A, Diaz-Sanchez D, Tong H. Effects of ambient ozone exposure on circulating extracellular vehicle microRNA levels in coronary artery disease patients. J Toxicol Environ Health A. 2020;83:1-12.

32. Clark ML, Bachand AM, Heiderscheidt JM, Yoder SA, Luna B, Volckens J, Koehler KA, Conway S, Reynolds SJ, Peel JL. Impact of a cleaner-burning cookstove intervention on blood pressure in Nicaraguan women. Indoor Air. 2013;23(2):105-14

33. Clark ML, Bazemore H, Reynolds SJ, Heiderscheidt JM, Conway S, Bachand AM, Volckens J, Peel JL. A baseline evaluation of traditional cook stove smoke exposures and indicators of cardiovascular and respiratory health among Nicaraguan women. Int J Occup Environ Health. 2011;17(2):113-21.

34. Clark SN, Schmidt AM, Carter EM, Schauer JJ, Yang X, Ezzati M, Daskalopoulou SS, Baumgartner J. Longitudinal evaluation of a household energy package on blood pressure, central hemodynamics, and arterial stiffness in China. Environ Res. 2019;177:108592.

35. Conklin DJ. Acute cardiopulmonary toxicity of inhaled aldehydes: role of TRPA1. Ann N Y Acad Sci. 2016;1374(1):59-67.

36. Cortelli P, Lombardi C, Montagna P, Parati G. Baroreflex modulation during sleep and in obstructive sleep apnea syndrome. Auton Neurosci. 2012; 169(1):7-11.

37. Crabbe H. Risk of respiratory and cardiovascular hospitalisation with exposure to bushfire particulates: new evidence from Darwin, Australia. Environ Geochem Health. 2012;34(6):697-709.

38. Croft DP, Cameron SJ, Morrell CN, Lowenstein CJ, Ling F, Zareba W, Hopke PK, Utell MJ, Thurston SW, Thevenet-Morrison K, Evans KA, Chalupa D, Rich 
DQ. Associations between ambient wood smoke and other particulate pollutants and biomarkers of systemic inflammation, coagulation and thrombosis in cardiac patients. Environ Res. 2017;154:352-61.

39. De Sales F, Okin GS, Xue Y, Dintwe K. On the effects of wildfires on precipitation in southern Africa. Clim Dyn. 2019;52(1):951-67.

40. Deflorio-Barker S, Crooks J, Reyes J, Rappold AG. Cardiopulmonary effects of fine particulate matter exposure among older adults, during wildfire and non-wildfire periods, in the United States 2008-2010. Environ Health Perspect. 2019;127(3):37006

41. Delfino RJ, Brummel S, Wu J, Stern H, Ostro B, Lipsett M, Winer A, Street DH, Zhang L, Tjoa T, Gillen DL. The relationship of respiratory and cardiovascular hospital admissions to the southern California wildfires of 2003. Occup Environ Med. 2009;66(3):189-97.

42. Deng Y, Gao Q, Yang D, Hua H, Wang N, Ou F, Liu R, Wu B, Liu Y. Association between biomass fuel use and risk of hypertension among Chinese older people: a cohort study. Environ Int. 2020;138:105620.

43. Dennekamp M, Straney LD, Erbas B, Abramson MJ, Keywood M, Smith K, Sim MR, Glass DC, Del Monaco A, Haikerwal A, Tonkin AM. Forest fire smoke exposures and out-of-hospital cardiac arrests in Melbourne, Australia: a Case-crossover study. Environ Health Perspect. 2015:123(10):959-64.

44. Díaz-Robles L, Cortés S, Vergara-Fernández A, Ortega JC. Short Term Health Effects of Particulate Matter: A Comparison between Wood Smoke and Multi-Source Polluted Urban Areas in Chile. Aerosol Air Qual Res. 2015;15: 306-18. https://doi.org/10.4209/aagr.2013.10.0316.

45. Evans KA, Hopke PK, Utell MJ, Kane C, Thurston SW, Ling FS, Chalupa D, Rich DQ. Triggering of ST-elevation myocardial infarction by ambient wood smoke and other particulate and gaseous pollutants. J Expo Sci Environ Epidemiol. 2017:27(2):198-206.

46. Farina F, Lonati E, Milani C, Massimino L, Ballarini E, Donzelli E, Crippa L, Marmiroli P, Botto L, Corsetto PA, Sancini G, Bulbarelli A, Palestini P. In vivo comparative study on acute and sub-acute biological effects induced by ultrafine particles of different anthropogenic sources in BALB/C mice. Int J Mol Sci. 2019;20(11):2805

47. Fatmi Z, Coggon D. Coronary heart disease and household air pollution from use of solid fuel: a systematic review. Br Med Bull. 2016;118(1):95-113.

48. Faustini A, Alessandrini ER, Pey J, Perez N, Samoli E, Querol X, Cadum E, Perrino C, Ostro B, Ranzi A, Sunyer J, Stafoggia M, Forastiere F. Short-term effects of particulate matter on mortality during forest fires in southern Europe: results of the MED-PARTICLES project. Occup Environ Med. 2015; 72(5):323-9.

49. Fedak KM, Good N, Walker ES, Balmes J, Brook RD, Clark ML, Cole-Hunter T, Devlin R, L'Orange C, Luckasen G, Mehaffy J, Shelton R, Wilson A, Volckens J, Peel JL. Acute effects on blood pressure following controlled exposure to Cookstove air pollution in the STOVES study. J Am Heart Assoc. 2019;8(14): e012246.

50. Forchhammer L, Møller P, Riddervold IS, Bønløkke J, Massling A, Sigsgaard T, Loft S. Controlled human wood smoke exposure: oxidative stress, inflammation and microvascular function. Part Fibre Toxicol. 2012;9:7.

51. Forouzanfar MH, Afshin A, Alexander LT, Ross Anderson H, Bhutta ZA, Biryukov S, Brauer M, Burnett R, Cercy K, Charlson FJ, Cohen AJ, Dandona L, Estep K, Ferrari AJ, Frostad JJ, Fullman N, Gething PW, Godwin WW, Griswold M, Hay SI, Kinfu Y, Kyu HH, Larson HJ, Liang X, Lim SS, Liu PY, Lopez AD, Lozano R, Marczak L, Mensah GA, Mokdad AH, Moradi-Lakeh M, Naghavi M, Neal B, Reitsma MB, Roth GA, Salomon JA, Sur PJ, Vos T, Wagner JA, Wang H, Zhao Y, Zhou M, Aasvang GM, Abajobir AA, Abate KH, Abbafati C, Abbas KM, Abd-Allah F, Abdulle AM, Abera SF, Abraham B, Abu-Raddad LJ, Abyu GY, Adebiyi AO, Adedeji IA, Ademi Z, Adou AK, Adsuar JC, Agardh EE, Agarwal A, Agrawal A, Kiadaliri AA, Ajala ON, Akinyemiju TF, Al-Aly Z, Alam K, Alam NKM, Aldhahri SF, Aldridge RW, Alemu ZA, Ali R, Alkerwi A'a, Alla F, Allebeck P, Alsharif U, Altirkawi KA, Martin EA, Alvis-Guzman N, Amare AT, Amberbir A, Amegah AK, Amini H, Ammar W, Amrock SM, Andersen $\mathrm{HH}$, Anderson BO, Antonio CAT, Anwari P, Ärnlöv J, Al Artaman HA, Asghar RJ, Assadi R, Atique S, Arthur Avokpaho EFG, Awasthi A, Quintanilla BPA, Azzopardi P, Bacha U, Badawi A, Bahit MC, Balakrishnan K, Barac A, Barber RM, Barker-Collo SL, Bärnighausen T, Barquera S, Barregard L, Barrero LH, Basu S, Batis C, Bazargan-Hejazi S, Beardsley J, Bedi N, Beghi E, Bell B, Bell ML, Bello AK, Bennett DA, Bensenor IM, Berhane A, Bernabé E, Betsu BD, Beyene AS, Bhala N, Bhansali A, Bhatt S, Biadgilign S, Bikbov B, Bisanzio D, Bjertness E, Blore JD, Borschmann R, Boufous S, Bourne RRA, Brainin M, Brazinova A,
Breitborde NJK, Brenner $H$, Broday DM, Brugha TS, Brunekreef B, Butt ZA, Cahill LE, Calabria B, Campos-Nonato IR, Cárdenas R, Carpenter DO, Carrero JJ, Casey DC, Castañeda-Orjuela CA, Rivas JC, Castro RE, CataláLópez F, Chang J-C, Chiang PP-C, Chibalabala M, Chimed-Ochir O, Chisumpa VH, Chitheer AA, Choi J-YJ, Christensen H, Christopher DJ, Ciobanu LG, Coates MM, Colquhoun SM, Contreras Manzano AG, Cooper LT, Cooperrider K, Cornaby L, Cortinovis M, Crump JA, CuevasNasu L, Damasceno A, Dandona R, Darby SC, Dargan PI, das Neves J, Davis AC, Davletov K, de Castro EF, De la Cruz-Góngora V, De Leo D, Degenhardt L, Del Gobbo LC, del Pozo-Cruz B, Dellavalle RP, Deribew A, Des Jarlais DC, Dharmaratne SD, Dhillon PK, Diaz-Torné C, Dicker D, Ding EL, Dorsey ER, Doyle KE, Driscoll TR, Duan L, Dubey M, Duncan $B B$, Elyazar I, Endries AY, Ermakov SP, Erskine HE, Eshrati B, Esteghamati A, Fahimi S, Faraon EJA, Farid TA, Sa Farinha CS e, Faro A, Farvid MS, Farzadfar $F$, Feigin $V L$, Fereshtehnejad S-M, Fernandes JG, Fischer $F$, Fitchett JRA, Fleming T, Foigt N, Foreman K, Fowkes FGR, Franklin RC, Fürst T, Futran ND, Gakidou E, Garcia-Basteiro AL, Gebrehiwot $T$, Gebremedhin AT, Geleijnse JM, Gessner BD, Giref AZ, Giroud M, Gishu MD, Giussani G, Goenka S, Gomez-Cabrera MC, Gomez-Dantes H, Gona P, Goodridge A, Gopalani SV, Gotay CC, Goto A, Gouda HN, Gugnani HC, Guillemin F, Guo Y, Gupta R, Gupta R, Gutiérrez RA, Haagsma JA, Hafezi-Nejad N, Haile D, Hailu GB, Halasa YA, Hamadeh RR, Hamidi S, Handal AJ, Hankey GJ, Hao Y, Harb HL, Harikrishnan S, Haro JM, Hassanvand MS, Hassen TA, Havmoeller R, Heredia-Pi IB, HernándezLlanes NF, Heydarpour P, Hoek HW, Hoffman HJ, Horino M, Horita N, Hosgood HD, Hoy DG, Hsairi M, Htet AS, Hu G, Huang JJ, Husseini A, Hutchings SJ, Huybrechts I, Iburg KM, Idrisov BT, lleanu BV, Inoue M, Jacobs TA, Jacobsen $\mathrm{KH}$, Jahanmehr $\mathrm{N}$, Jakovljevic MB, Jansen HAFM, Jassal SK, Javanbakht M, Jayaraman SP, Jayatilleke AU, Jee SH, Jeemon $P$, Jha $V$, Jiang $Y$, Jibat $T$, Jin $Y$, Johnson CO, Jonas JB, Kabir Z, Kalkonde Y, Kamal R, Kan H, Karch A, Karema CK, Karimkhani C, Kasaeian A, Kaul A, Kawakami N, Kazi DS, Keiyoro PN, Kemmer L, Kemp AH, Kengne AP, Keren A, Kesavachandran CN, Khader YS, Khan AR, Khan EA, Khan G, Khang Y-H, Khatibzadeh S, Khera S, Khoja TAM, Khubchandani J, Kieling C, Kim C-i, Kim D, Kimokoti RW, Kissoon N, Kivipelto M, Knibbs LD, Kokubo Y, Kopec JA, Koul PA, Koyanagi A, Kravchenko M, Kromhout H, Krueger $H$, Ku T, Defo BK, Kuchenbecker RS, Bicer BK, Kuipers EJ, Kumar GA, Kwan GF, Lal DK, Lalloo R, Lallukka T, Lan Q, Larsson A, Latif AA, Lawrynowicz AEB, Leasher JL, Leigh J, Leung J, Levi M, Li X, Li Y, Liang J, Liu S, Lloyd BK, Logroscino G, Lotufo PA, Lunevicius R, Macintyre M, Mahdavi M, Majdan M, Majeed A, Malekzadeh R, Malta DC, Manamo WAA, Mapoma CC, Marcenes W, Martin RV, Martinez-Raga J, Masiye F, Matsushita K, Matzopoulos R, Mayosi BM, McGrath JJ, McKee M, Meaney PA, Medina C, Mehari A, Mejia-Rodriguez F, Mekonnen AB, Melaku YA Memish ZA, Mendoza W, Mensink GBM, Meretoja A, Meretoja TJ, Mesfin YM, Mhimbira FA, Millear A, Miller TR, Mills EJ, Mirarefin M, Misganaw A Mock CN, Mohammadi A, Mohammed S, Mola GLD, Monasta L, Hernandez JCM, Montico M, Morawska L, Mori R, Mozaffarian D, Mueller UO, Mullany E, Mumford JE, Murthy GVS, Nachega JB, Naheed A, Nangia $\mathrm{V}$, Nassiri N, Newton JN, Ng M, Le Nguyen Q, Nisar Ml, Pete PMN, Norheim OF, Norman RE, Norrving B, Nyakarahuka L, Obermeyer CM, Ogbo FA, Oh I-H, Oladimeji O, Olivares PR, Olsen H, Olusanya BO, Olusanya JO, Opio JN, Oren E, Orozco R, Ortiz A, Ota E, Pa M, Pana A, Park E-K, Parry CD, Parsaeian M, Patel T, Paternina Caicedo AJ, Patil ST, Patten SB, Patton GC, Pearce N, Pereira DM, Perico N, Pesudovs K Petzold M, Phillips MR, Piel FB, Pillay JD, Plass D, Polinder S, Pond CD, Pope CA, Pope D, Popova S, Poulton RG, Pourmalek F, Prasad NM, Qorbani M, Rabiee RHS, Radfar A, Rafay A, Rahimi-Movaghar V, Rahman M, Rahman MHU, Rahman SU, Rai RK, Rajsic S, Raju M, Ram U, Rana SM, Ranganathan K, Rao P, García CAR, Refaat AH, Rehm CD, Rehm J, Reinig N, Remuzzi G, Resnikoff S, Ribeiro AL, Rivera JA, Roba HS, Rodriguez A, Rodriguez-Ramirez S, Rojas-Rueda D, Roman Y, Ronfani L, Roshandel G, Rothenbacher D, Roy A, Saleh MM, Sanabria JR, SanchezRiera L, Sanchez-Niño MD, Sánchez-Pimienta TG, Sandar L, Santomauro DF, Santos IS, Sarmiento-Suarez R, Sartorius B, Satpathy M, Savic M, Sawhney M, Schmidhuber J, Schmidt MI, Schneider IJC, Schöttker B, Schutte AE, Schwebel DC, Scott JG, Seedat S, Sepanlou SG, Servan-Mori EE, Shaddick G, Shaheen A, Shahraz S, Shaikh MA, Levy TS, Sharma R, She J, Sheikhbahaei S, Shen J, Sheth KN, Shi P, Shibuya K, Shigematsu M, Shin M-J, Shiri R, Shishani K, Shiue I, Shrime MG, Sigfusdottir ID, Silva DAS, Silveira DGA, Silverberg II, Simard EP, Sindi S, Singh A, Singh 
JA, Singh PK, Slepak EL, Soljak M, Soneji S, Sorensen RJD, Sposato LA, Sreeramareddy CT, Stathopoulou V, Steckling N, Steel N, Stein DJ, Stein MB, Stöckl H, Stranges S, Stroumpoulis K, Sunguya BF, Swaminathan S, Sykes BL, Szoeke CEl, Tabarés-Seisdedos R, Takahashi K, Talongwa RT, Tandon N, Tanne D, Tavakkoli M, Taye BW, Taylor HR, Tedla BA, Tefera WM, Tegegne TK, Tekle DY, Terkawi AS, Thakur JS, Thomas BA, Thomas ML, Thomson AJ, Thorne-Lyman AL, Thrift AG, Thurston GD, Tillmann T, Tobe-Gai R, Tobollik M, Topor-Madry R, Topouzis F, Towbin JA, Tran BX, Dimbuene ZT, Tsilimparis N, Tura AK, Tuzcu EM, Tyrovolas S, Ukwaja KN, Undurraga EA, Uneke CJ, Uthman OA, van Donkelaar A, van Os J, Varakin YY, Vasankari T, Veerman JL, Venketasubramanian N, Violante FS, Vollset SE, Wagner GR, Waller SG, Wang JL, Wang L, Wang Y, Weichenthal S, Weiderpass E, Weintraub RG, Werdecker A, Westerman R, Whiteford HA, Wijeratne $T$, Wiysonge CS, Wolfe CDA, Won $S$, Woolf AD, Wubshet M, Xavier D, Xu G, Yadav AK, Yakob B, Yalew AZ, Yano Y, Yaseri M, Ye P, Yip P, Yonemoto N, Yoon S-J, Younis MZ, Yu C, Zaidi Z, Zaki MES, Zhu J, Zipkin B, Zodpey S, Zuhlke LJ, Murray CJL. Global, regional, and national comparative risk assessment of 79 behavioural, environmental and occupational, and metabolic risks or clusters of risks, 1990-2015: a systematic analysis for the global burden of disease study 2015. Lancet. 2016;388(10053):1659-724.

52. Furuyama A, Kanno S, Kobayashi T, Hirano S. Extrapulmonary translocation of intratracheally instilled fine and ultrafine particles via direct and alveolar macrophage-associated routes. Arch Toxicol. 2009;83(5):429-37.

53. Gan RW, Ford B, Lassman W, Pfister G, Vaidyanathan A, Fischer E, Volckens J, Pierce JR, Magzamen S. Comparison of wildfire smoke estimation methods and associations with cardiopulmonary-related hospital admissions. Geohealth. 2017;1(3):122-36.

54. Garcia-Olivé I, Radua J, Salvador R, Marin A. Association between Forest fires, environmental temperature and cardiorespiratory admissions from 2005 to 2014. Arch Bronconeumol. 2017;53(9):525-7.

55. Gaughan DM, Siegel PD, Hughes MD, Chang CY, Law BF, Campbell CR, Richards JC, Kales SF, Chertok M, Kobzik L, Nguyen PS, O'Donnell CR, Kiefer M, Wagner GR, Christiani DC. Arterial stiffness, oxidative stress, and smoke exposure in wildland firefighters. Am J Ind Med. 2014;57(7):748-56.

56. Gerde P, Muggenburg BA, Lundborg M, Dahl AR. The rapid alveolar absorption of diesel soot-adsorbed benzo[a]pyrene: bioavailability, metabolism and dosimetry of an inhaled particle-borne carcinogen. Carcinogenesis. 2001;22(5):741-9.

57. Ghio AJ, Carraway MS, Madden MC. Composition of air pollution particles and oxidative stress in cells, tissues, and living systems. J Toxicol Environ Health B Crit Rev. 2012a;15(1):1-21.

58. Ghio AJ, Soukup JM, Case M, Dailey LA, Richards J, Berntsen J, Devlin $R B$, Stone $S$, Rappold A. Exposure to wood smoke particles produces inflammation in healthy volunteers. Occup Environ Med. 2012b;69(3): $170-5$.

59. Ghio AJ, Soukup JM, Dailey LA, Madden MC. Air pollutants disrupt iron homeostasis to impact oxidant generation, biological effects, and tissue injury. Free Radic Biol Med. 2020;151:38-55.

60. Gilardoni S, Massoli P, Paglione M, Giulianelli L, Carbone C, Rinaldi M, Decesari S, Sandrini S, Costabile F, Gobbi GP, Pietrogrande MC, Visentin M, Scotto F, Fuzzi S, Facchini MC. Direct observation of aqueous secondary organic aerosol from biomass-burning emissions. Proc Natl Acad Sci U S A. 2016;113(36):10013-8.

61. Golpe R, Sanjuan-Lopez P, Martin-Robles I, Gonzalez-Juanatey C, Perez-deLlano L, Lopez-Campos JL. Cardiovascular studies in patients with chronic obstructive pulmonary disease due to biomass smoke or tobacco. Lung. 2018;196(2):195-200.

62. Grace MS, Belvisi MG. TRPA1 receptors in cough. Pulm Pharmacol Ther. 2011;24(3):286-8.

63. Grilli A, Bengalli R, Longhin E, Capasso L, Proverbio MC, Forcato M, Bicciato S, Gualtieri M, Battaglia C, Camatini M. Transcriptional profiling of human bronchial epithelial cell BEAS-2B exposed to diesel and biomass ultrafine particles. Bmc Genomics. 2018;19:302.

64. Haikerwal A, Akram M, Del Monaco A, Smith K, Sim MR, Meyer M, Tonkin AM, Abramson MJ, Dennekamp M. Impact of fine particulate matter (PM2.5) exposure during wildfires on cardiovascular health outcomes. J Am Heart Assoc. 2015;4(7):e001653.

65. Hanigan IC, Johnston FH, Morgan GG. Vegetation fire smoke, indigenous status and cardio-respiratory hospital admissions in Darwin, Australia, 19962005: a time-series study. Environ Health. 2008;7:42.
66. Hejl AM, Adetona O, Diaz-Sanchez D, Carter JD, Commodore AA, Rathbun SL, Naeher LP. Inflammatory effects of woodsmoke exposure among wildland firefighters working at prescribed burns at the Savannah River site, SC. J Occup Environ Hyg. 2013;10(4):173-80.

67. Henderson SB, Brauer M, MacNab YC, Kennedy SM. Three measures of Forest fire smoke exposure and their associations with respiratory and cardiovascular health outcomes in a population-based cohort. Environ Health Perspect. 2011;119(9):1266-71.

68. Henderson SB, Brauet M, Kennedy S, MacNab Y. Three measures of Forest fire smoke exposure and their association with respiratory and cardiovascular physician visits and hospital admissions. Epidemiology. 2009; 20(6):S82.

69. Heron M. Deaths: leading causes for 2016. Natl Vital Stat Rep. 2018;67(6):177.

70. Holme JA, Brinchmann BC, Refsnes M, Lag M, Ovrevik J. Potential role of polycyclic aromatic hydrocarbons as mediators of cardiovascular effects from combustion particles. Environ Health. 2019;18(1):74.

71. Hunter AL, Unosson J, Bosson JA, Langrish JP, Pourazar J, Raftis JB, Miller MR, Lucking AJ, Boman C, Nyström R, Donaldson K, Flapan AD, Shah AS, Pung L, Sadiktsis I, Masala S, Westerholm R, Sandström T, Blomberg A, Newby DE, Mills NL. Effect of wood smoke exposure on vascular function and thrombus formation in healthy fire fighters. Part Fibre Toxicol. 2014;11: 62.

72. Huynh QL, Blizzard CL, Marwick TH, Negishi K. Association of ambient particulate matter with heart failure incidence and all-cause readmissions in Tasmania: an observational study. BMJ Open. 2018;8(5):e021798.

73. Johnston FH, Bailie RS, Pilotto LS, Hanigan IC. Ambient biomass smoke and cardio-respiratory hospital admissions in Darwin, Australia. Bmc Public Health. 2007;7:240

74. Johnston FH, Hanigan IC, Henderson SB, Morgan GG. Evaluation of interventions to reduce air pollution from biomass smoke on mortality in Launceston, Australia: retrospective analysis of daily mortality, 1994-2007. BMJ. 2013;346:e8446.

75. Johnston FH, Henderson SB, Chen Y, Randerson JT, Marlier M, Defries RS, Kinney P, Bowman DM, Brauer M. Estimated global mortality attributable to smoke from landscape fires. Environ Health Perspect. 2012a;120(5):695-701.

76. Johnston FH, Purdie S, Jalaludin B, Martin KL, Henderson SB, Morgan GG. Air pollution events from forest fires and emergency department attendances in Sydney, Australia 1996-2007: a case-crossover analysis. Environ Health. 2014;13:105.

77. Jones CG, Rappold AG, Vargo J, Cascio WE, Kharrazi M, McNally B, Hoshiko S, Cares Surveillance Group with the. Out-of-hospital cardiac arrests and wildfire-related particulate matter during 2015-2017 California wildfires. J Am Heart Assoc. 2020;9(8):e014125.

78. Kajbafzadeh M, Brauer M, Karlen B, Carlsten C, van Eeden S, Allen RW. The impacts of traffic-related and woodsmoke particulate matter on measures of cardiovascular health: a HEPA filter intervention study. Occup Environ Med. 2015;72(6):394-400.

79. Kampa M, Castanas E. Human health effects of air pollution. Environ Pollut. 2008;151(2):362-7.

80. Kargin R, Kargin F, Mutlu H, Emiroglu Y, Pala S, Akcakoyun M, Aung SM, Baran R, Ozdemir N. Long-term exposure to biomass fuel and its relation to systolic and diastolic biventricular performance in addition to obstructive and restrictive lung diseases. Echocardiography. 2011;28(1):52-61.

81. Kim YH, King C, Krantz T, Hargrove MM, George IJ, McGee J, Copeland L, Hays MD, Landis MS, Higuchi M, Gavett SH, Gilmour MI. The role of fuel type and combustion phase on the toxicity of biomass smoke following inhalation exposure in mice. Arch Toxicol. 2019;93(6):1501-13.

82. Kim YH, Tong H, Daniels M, Boykin E, Krantz QT, McGee J, Hays M, Kovalcik K, Dye JA, Gilmour MI. Cardiopulmonary toxicity of peat wildfire particulate matter and the predictive utility of precision cut lung slices. Part Fibre Toxicol. 2014;11:29.

83. Kim YH, Warren SH, Krantz QT, King C, Jaskot R, Preston WT, George BJ, Hays MD, Landis MS, Higuchi M, DeMarini DM, Gilmour MI. Mutagenicity and lung toxicity of smoldering vs. Flaming Emissions from Various Biomass Fuels: Implications for Health Effects from Wildland Fires. Environ Health Perspect. 2018;126(1):017011

84. Kollanus V , Tiittanen P, Niemi JV, Lanki T. Effects of long-range transported air pollution from vegetation fires on daily mortality and hospital admissions in the Helsinki metropolitan area, Finland. Environ Res. 2016;151: 351-8. 
85. Le GE, Breysse PN, McDermott A, Eftim SE, Geyh A, Berman JD, Curriero FC. Canadian Forest fires and the effects of Long-range Transboundary air pollution on hospitalizations among the elderly. ISPRS Int J Geo Inf. 2014; 3(2):713-31.

86. Lee TS, Falter K, Meyer P, Mott J, Gwynn C. Risk factors associated with clinic visits during the 1999 forest fires near the Hoopa Valley Indian reservation, California, USA. Int J Environ Health Res. 2009;19(5):315-27.

87. Linares C, Carmona R, Tobías A, Mirón IJ, Díaz J. Influence of advections of particulate matter from biomass combustion on specific-cause mortality in Madrid in the period 2004-2009. Environ Sci Pollut Res Int. 2015; 22(9):7012-9.

88. Liu JC, Wilson A, Mickley $\amalg$, Dominici F, Ebisu K, Wang Y, Sulprizio MP, Peng RD, Yue X, Son JY, Anderson GB, Bell ML. Wildfire-specific fine particulate matter and risk of hospital admissions in urban and rural counties. Epidemiology. 2017;28(1):77-85.

89. Liu PL, Chen YL, Chen YH, Lin SJ, Kou YR. Wood smoke extract induces oxidative stress-mediated caspase-independent apoptosis in human lung endothelial cells: role of AIF and EndoG. Am J Physiol Lung Cell Mol Physiol. 2005:289(5):L739-49.

90. Longhin E, Gualtieri M, Capasso L, Bengalli R, Mollerup S, Holme JA, Ovrevik J, Casadei S, Di Benedetto C, Parenti P, Camatini M. Physico-chemical properties and biological effects of diesel and biomass particles. Environ Pollut. 2016;215:366-75.

91. Lopez-Barneo J, Ortega-Saenz P, Pardal R, Pascual A, Piruat J. Carotid body oxygen sensing. Eur Respir J. 2008:32(5):1386-98.

92. Marlier ME, DeFries RS, Voulgarakis A, Kinney PL, Randerson JT, Shindell DT Chen Y, Faluvegi G. El Nino and health risks from landscape fire emissions in Southeast Asia. Nat Clim Chang. 2013;3(2):131-6.

93. Martin BL, Thompson LC, Kim Y, Williams W, Snow SJ, Schladweiler MC, Phillips P, King C, Richards J, Haykal-Coates N, Higuchi M, Gilmour MI, Kodavanti UP, Hazari MS, Farraj AK. Acute peat smoke inhalation sensitizes rats to the postprandial cardiometabolic effects of a high fat oral load. Sci Total Environ. 2018;643:378-91.

94. Martin KL, Hanigan IC, Morgan GG, Henderson SB, Johnston FH. Air pollution from bushfires and their association with hospital admissions in Sydney, Newcastle and Wollongong, Australia 1994-2007. Aust N Z J Public Health. 2013;37(3):238-43.

95. Mazzone SB, Undem BJ. Vagal afferent innervation of the Airways in Health and Disease. Physiol Rev. 2016;96(3):975-1024.

96. Medina-Ramon M, Schwartz J. Who is more vulnerable to die from ozone air pollution? Epidemiology. 2008;19(5):672-9.

97. Miller MR. Oxidative stress and the cardiovascular effects of air pollution Free Radic Biol Med. 2020;151:69-87.

98. Miller MR, Raftis JB, Langrish JP, McLean SG, Samutrtai P, Connell SP, Wilson S, Vesey AT, Fokkens PHB, Boere AJF, Krystek P, Campbell CJ, Hadoke PWF, Donaldson K, Cassee FR, Newby DE, Duffin R, Mills NL. Inhaled nanoparticles accumulate at sites of vascular disease. ACS Nano. 2017;11(5):4542-52.

99. Miller MR, Shaw CA, Langrish JP. From particles to patients: oxidative stress and the cardiovascular effects of air pollution. Futur Cardiol. 2012:8(4): 577-602.

100. Miousse IR, Chalbot MC, Pathak R, Lu X, Nzabarushimana E, Krager K, AykinBurns N, Hauer-Jensen M, Demokritou P, Kavouras IG, Koturbash I. In vitro toxicity and Epigenotoxicity of different types of ambient particulate matter. Toxicol Sci. 2015;148(2):473-87.

101. Misra A, Longnecker MP, Dionisio KL, Bornman RMS, Travlos GS, Brar S, Whitworth KW. Household fuel use and biomarkers of inflammation and respiratory illness among rural south African women. Environ Res. 2018;166: 112-6.

102. Mitter SS, Vedanthan R, Islami F, Pourshams A, Khademi H, Kamangar F, Abnet CC, Dawsey SM, Pharoah PD, Brennan P, Fuster V, Boffetta P, Malekzadeh R. Household fuel use and cardiovascular disease mortality Golestan cohort study. Circulation. 2016;133(24):2360.

103. Moore D, Copes R, Fisk R, Joy R, Chan K, Brauer M. Population health effects of air quality changes due to forest fires in British Columbia in 2003 estimates from physician-visit billing data. Can J Public Health. 2006;97(2): 105-8.

104. Morgan G, Sheppeard V, Khalaj B, Ayyar A, Lincoln D, Jalaludin B, Beard J, Corbett $\mathrm{S}$, Lumley $\mathrm{T}$. Effects of bushfire smoke on daily mortality and hospital admissions in Sydney, Australia. Epidemiology. 2010;21(1):47-55.

105. Mott JA, Mannino DM, Alverson CJ, Kiyu A, Hashim J, Lee T, Falter K, Redd SC. Cardiorespiratory hospitalizations associated with smoke exposure during the 1997, southeast Asian forest fires. Int J Hyg Environ Health. 2005; 208(1-2):75-85.

106. Muala A, Rankin G, Sehlstedt M, Unosson J, Bosson JA, Behndig A, Pourazar J, Nystrom R, Pettersson E, Bergvall C, Westerholm R, Jalava PI, Happo MS, Uski O, Hirvonen MR, Kelly FJ, Mudway IS, Blomberg A, Boman C, Sandstrom T. Acute exposure to wood smoke from incomplete combustion indications of cytotoxicity. Part Fibre Toxicol. 2015;12:33.

107. Navarro KM, Kleinman MT, Mackay CE, Reinhardt TE, Balmes JR, Broyles GA, Ottmar RD, Naher LP, Domitrovich JW. Wildland firefighter smoke exposure and risk of lung cancer and cardiovascular disease mortality. Environ Res. 2019;173:462-8.

108. Newby DE, Mannucci PM, Tell GS, Baccarelli AA, Brook RD, Donaldson K, Forastiere F, Franchini M, Franco OH, Graham I, Hoek G, Hoffmann B, Hoylaerts MF, Kunzli N, Mills N, Pekkanen J, Peters A, Piepoli MF, Rajagopalan S, Storey RF, European Association for Cardiovascular Prevention Esc Working Group on Thrombosis, Rehabilitation, and E. S. C. Heart Failure Association. Expert position paper on air pollution and cardiovascular disease. Eur Heart J. 2015;36(2):83-93b.

109. Nunes KVR, Ignotti E, Hacon SD. Circulatory disease mortality rates in the elderly and exposure to PM2.5 generated by biomass burning in the Brazilian Amazon in 2005. Cadernos De Saude Publica. 2013;29(3):589-98.

110. Oliveira M, Costa S, Vaz J, Fernandes A, Slezakova K, Delerue-Matos C, Teixeira JP, Pereira MC, Morais S. Firefighters exposure to fire emissions: impact on levels of biomarkers of exposure to polycyclic aromatic hydrocarbons and genotoxic/oxidative-effects. J Hazard Mater. 2020;383: 121179.

111. Ostro B, Malig B, Hasheminassab S, Berger K, Chang E, Sioutas C. Associations of source-specific fine particulate matter with emergency department visits in California. Am J Epidemiol. 2016;184(6):450-9.

112. Painschab MS, Davila-Roman VG, Gilman RH, Vasquez-Villar AD, Pollard SL, Wise RA, Miranda JJ, Checkley W. Chronic exposure to biomass fuel is associated with increased carotid artery intima-media thickness and a higher prevalence of atherosclerotic plaque. Heart. 2013;99(14):984-91.

113. Palm BB, Campuzano-Jost P, Day DA, Ortega AM, Fry JL, Brown SS, Zarzana KJ, Dube W, Wagner NL, Draper DC, Kaser L, Jud W, Karl T, Hansel A, Gutiérrez-Montes C, Jimenez JL. Secondary organic aerosol formation from in situ $\mathrm{OH}, \mathrm{O} 3$, and $\mathrm{NO} 3$ oxidation of ambient forest air in an oxidation flow reactor. Atmos Chem Phys. 2017;17(8):5331-54.

114. Parthum B, Pindilli E, Hogan D. Benefits of the fire mitigation ecosystem service in the great dismal swamp National Wildlife Refuge, Virginia, USA. J Environ Manag. 2017;203(Pt 1):375-82.

115. Pausas JG, Keeley JE. Wildfires as an ecosystem service. Front Ecol Environ. 2019;17(5):289-95

116. Perez CM, Hazari MS, Farraj AK. Role of autonomic reflex arcs in cardiovascular responses to air pollution exposure. Cardiovasc Toxicol. 2015; 15(1):69-78.

117. Radeloff VC, Helmers DP, Kramer HA, Mockrin MH, Alexandre PM, BarMassada A, Butsic V, Hawbaker TJ, Martinuzzi S, Syphard AD, Stewart SI. Rapid growth of the US wildland-urban interface raises wildfire risk. Proc Natl Acad Sci U S A. 2018;115(13):3314-9.

118. Rappold AG, Cascio WE, Kilaru VJ, Stone SL, Neas LM, Devlin RB, DiazSanchez D. Cardio-respiratory outcomes associated with exposure to wildfire smoke are modified by measures of community health. Environ Health. 2012;11:71

119. Rappold AG, Fann NL, Crooks J, Huang J, Cascio WE, Devlin RB, DiazSanchez D. Forecast-based interventions can reduce the health and economic burden of wildfires. Environ Sci Technol. 2014;48(18):10571-9.

120. Rappold AG, Reyes J, Pouliot G, Cascio WE, Diaz-Sanchez D. Community vulnerability to health impacts of Wildland fire smoke exposure. Environ Sci Technol. 2017;51(12):6674-82.

121. Rappold AG, Stone SL, Cascio WE, Neas LM, Kilaru VJ, Carraway MS, Szykman $\mathrm{J}$, Ising A, Cleve WE, Meredith JT, Vaughan-Batten H, Deyneka L, Devlin RB. Peat bog wildfire smoke exposure in rural North Carolina is associated with cardiopulmonary emergency department visits assessed through Syndromic surveillance. Environ Health Perspect. 2011;119(10):1415-20.

122. Reed MD, Campen MJ, Gigliotti AP, Harrod KS, McDonald JD, Seagrave JC, Mauderly JL, Seilkop SK. Health effects of subchronic exposure to environmental levels of hardwood smoke. Inhal Toxicol. 2006;18(8):523-39.

123. Reid CE, Brauer M, Johnston FH, Jerrett M, Balmes JR, Elliott CT. Critical review of health impacts of wildfire smoke exposure. Environ Health Perspect. 2016a;124(9):1334-43. 
124. Reid CE, Jerrett M, Tager IB, Petersen ML, Mann JK, Balmes JR. Differential respiratory health effects from the 2008 northern California wildfires: a spatiotemporal approach. Environ Res. 2016b;150:227-35.

125. Reisen F, Brown SK. Australian firefighters' exposure to air toxics during bushfire burns of autumn 2005 and 2006. Environ Int. 2009;35(2):342-52.

126. Resnick A, Woods B, Krapfl H, Toth B. Health outcomes associated with smoke exposure in Albuquerque, New Mexico, during the 2011 wallow fire. J Public Health Manag Pract. 2015;21(Suppl 2):S55-61.

127. Rich DQ, Utell MJ, Croft DP, Thurston SW, Thevenet-Morrison K, Evans KA, Ling FS, Tian Y, Hopke PK. Daily land use regression estimated woodsmoke and traffic pollution concentrations and the triggering of ST-elevation myocardial infarction: a case-crossover study. Air Qual Atmos Health. 2018;11(2):239-44.

128. Rodosthenous RS, Coull BA, Lu Q, Vokonas PS, Schwartz JD, Baccarelli AA. Ambient particulate matter and microRNAs in extracellular vesicles: a pilot study of older individuals. Part Fibre Toxicol. 2016;13:13.

129. Rodosthenous RS, Kloog I, Colicino E, Zhong J, Herrera LA, Vokonas P, Schwartz J, Baccarelli AA, Prada D. Extracellular vesicle-enriched microRNAs interact in the association between long-term particulate matter and blood pressure in elderly men. Environ Res. 2018;167:640-9.

130. Routledge HC, Manney S, Harrison RM, Ayres JG, Townend JN. Effect of inhaled Sulphur dioxide and carbon particles on heart rate variability and markers of inflammation and coagulation in human subjects. Heart. 2006; 92(2):220-7

131. Ruiz-Vera T, Ochoa-Martínez ÁC, Pruneda-Álvarez LG, Zarazúa S, PérezMaldonado IN. Exposure to biomass smoke is associated with an increased expression of circulating miRNA-126 and miRNA-155 in Mexican women: a pilot study. Drug Chem Toxicol. 2019;42(3):335-42.

132. Ruiz-Vera T, Pruneda-Álvarez LG, Ochoa-Martínez ÁC, Ramírez-GarcíaLuna JL, Pierdant-Pérez M, Gordillo-Moscoso AA, Pérez-Vázquez FJ, Pérez-Maldonado IN. Assessment of vascular function in Mexican women exposed to polycyclic aromatic hydrocarbons from wood smoke. Environ Toxicol Pharmacol. 2015;40(2):423-9.

133. Salimi F, Henderson SB, Morgan GG, Jalaludin B, Johnston FH. Ambient particulate matter, landscape fire smoke, and emergency ambulance dispatches in Sydney, Australia. Environ Int. 2017;99:208-12.

134. Samet JM, Chen H, Pennington ER, Bromberg PA. Non-redox cycling mechanisms of oxidative stress induced by PM metals. Free Radic Biol Med. 2020;151:26-37.

135. Sanhueza PA, Torreblanca MA, Diaz-Robles LA, Schiappacasse LN, Silva MP Astelle TD. Particulate air pollution and health effects for cardiovascular and respiratory causes in Temuco, Chile: a wood-smoke-polluted urban area. J Air Waste Manage Assoc. 2009;59(12):1481-8.

136. Schmid O, Moller W, Semmler-Behnke M, Ferron GA, Karg E, Lipka J, Schulz $H$, Kreyling WG, Stoeger T. Dosimetry and toxicology of inhaled ultrafine particles. Biomarkers. 2009;14(Suppl 1):67-73.

137. Schranz Cl, Castillo EM, Vilke GM. The 2007 San Diego wildfire impact on the emergency department of the University of California, San Diego hospital system. Prehosp Disaster Med. 2010;25(5):472-6.

138. Schwartz C, Bølling AK, Carlsten C. Controlled human exposures to wood smoke: a synthesis of the evidence. Part Fibre Toxicol. 2020;17(1):49.

139. Seaton A, MacNee W, Donaldson K, Godden D. Particulate air pollution and acute health effects. Lancet. 1995;345(8943):176-8.

140. Seilkop SK, Campen MJ, Lund AK, McDonald JD, Mauderly JL. Identification of chemical components of combustion emissions that affect proatherosclerotic vascular responses in mice. Inhal Toxicol. 2012;24(5):270-87.

141. Sertogullarindan B, Gumrukcuoglu HA, Sezgi C, Akil MA. Frequency of pulmonary hypertension in patients with COPD due to biomass smoke and tobacco smoke. Int J Med Sci. 2012;9(6):406-12.

142. Shan M, Yang X, Ezzati M, Chaturvedi N, Coady E, Hughes A, Shi Y, Yang M, Zhang $Y$, Baumgartner J. A feasibility study of the association of exposure to biomass smoke with vascular function, inflammation, and cellular aging. Environ Res. 2014;135:165-72.

143. Shaposhnikov D, Revich B, Bellander T, Bedada GB, Bottai M, Kharkova T, Kvasha E, Lezina E, Lind T, Semutnikova E, Pershagen G. Mortality related to air pollution with the Moscow heat wave and wildfire of 2010. Epidemiology. 2014;25(3):359-64.

144. Stockfelt L, Sallsten G, Almerud P, Basu S, Barregard L. Short-term chamber exposure to low doses of two kinds of wood smoke does not induce systemic inflammation, coagulation or oxidative stress in healthy humans. Inhal Toxicol. 2013;25(8):417-25.
145. Stockfelt L, Sallsten G, Olin AC, Almerud P, Samuelsson L, Johannesson S, Molnar P, Strandberg B, Almstrand AC, Bergemalm-Rynell K, Barregard L. Effects on airways of short-term exposure to two kinds of wood smoke in a chamber study of healthy humans. Inhal Toxicol. 2012;24(1):47-59.

146. Stone V, Miller MR, Clift MJD, Elder A, Mills NL, Moller P, Schins RPF, Vogel U, Kreyling WG, Alstrup Jensen $K$, Kuhlbusch TAJ, Schwarze PE, Hoet $P$, Pietroiusti A, De Vizcaya-Ruiz A, Baeza-Squiban A, Teixeira JP, Tran CL, Cassee FR. Nanomaterials versus ambient ultrafine particles: an opportunity to exchange toxicology knowledge. Environ Health Perspect. 2017;125(10): 106002.

147. Stowell JD, Geng GN, Saikawa E, Chang HH, Fu JS, Yang CE, Zhu QZ, Liu Y, Strickland MJ. Associations of wildfire smoke PM2.5 exposure with cardiorespiratory events in Colorado 2011-2014. Environ Int. 2019;133: 105151.

148. Thompson LC, Kim YH, Martin BL, Ledbetter AD, Dye JA, Hazari MS, Gilmour MI, Farraj AK. Pulmonary exposure to peat smoke extracts in rats decreases expiratory time and increases left heart end systolic volume. Inhal Toxicol. 2018;30(11-12):439-47.

149. Tinling MA, West JJ, Cascio WE, Kilaru V, Rappold AG. Repeating cardiopulmonary health effects in rural North Carolina population during a second large peat wildfire. Environ Health. 2016;15:12.

150. Tong H, Rappold AG, Diaz-Sanchez D, Steck SE, Berntsen J, Cascio WE, Devlin RB, Samet JM. Omega-3 fatty acid supplementation appears to attenuate particulate air pollution-induced cardiac effects and lipid changes in healthy middle-aged adults. Environ Health Perspect. 2012;120(7):952-7.

151. Tsuji H, Larson MG, Venditti FJ Jr, Manders ES, Evans JC, Feldman CL, Levy D. Impact of reduced heart rate variability on risk for cardiac events. The Framingham heart study. Circulation. 1996;94(11):2850-5.

152. Turner MC, Cohen A, Burnett RT, Jerrett M, Diver WR, Gapstur SM, Krewski D, Samet JM, Pope CA 3rd. Interactions between cigarette smoking and ambient PM2.5 for cardiovascular mortality. Environ Res. 2017;154:304-10.

153. Uda SK, Hein L, Atmoko D. Assessing the health impacts of peatland fires: a case study for Central Kalimantan, Indonesia. Environ Sci Pollut Res. 2019; 26(30):31315-27.

154. Unosson J, Blomberg A, Sandstrom T, Muala A, Boman C, Nystrom R, Westerholm R, Mills NL, Newby DE, Langrish JP, Bosson JA. Exposure to wood smoke increases arterial stiffness and decreases heart rate variability in humans. Part Fibre Toxicol. 2013;10:20.

155. Urbanski SP, Hao WM, Baker S. Chapter 4 chemical composition of Wildland fire emissions. In: Bytnerowicz A, Arbaugh MJ, Riebau AR, Andersen C, editors. Developments in Environmental Science, vol. 8. Amsterdam: Elsevier; 2008. p. 79-107.

156. van der Werf GR, Randerson JT, Giglio L, Collatz GJ, Mu M, Kasibhatla PS, Morton DC, DeFries RS, Jin Y, van Leeuwen $\Pi$. Global fire emissions and the contribution of deforestation, savanna, forest, agricultural, and peat fires (1997-2009). Atmos Chem Phys. 2010;10(23):11707-35.

157. Vedal S, Dutton SJ. Wildfire air pollution and daily mortality in a large urban area. Environ Res. 2006;102(1):29-35.

158. Walker ES, Fedak KM, Good N, Balmes J, Brook RD, Clark ML, Cole-Hunter T, Dinenno F, Devlin RB, L'Orange C, Luckasen G, Mehaffy J, Shelton R, Wilson A, Volckens J, Peel JL. Acute differences in pulse wave velocity, augmentation index, and central pulse pressure following controlled exposures to cookstove air pollution in the subclinical tests of volunteers exposed to smoke (SToVES) study. Environ Res. 2020;180:108831.

159. Wang Y, Hopke PK, Rattigan OV, Chalupa DC, Utell MJ. Multiple-year black carbon measurements and source apportionment using delta-C in Rochester, New York. J Air Waste Manag Assoc. 2012;62(8):880-7. https://doi. org/10.1080/10962247.2012.671792

160. Weichenthal S, Kulka R, Lavigne E, van Rijswijk D, Brauer M, Villeneuve PJ, Stieb D, Joseph L, Burnett RT. Biomass burning as a source of ambient fine particulate air pollution and acute myocardial infarction. Epidemiology. 2017;28(3):329-37.

161. Wettstein ZS, Hoshiko S, Fahimi J, Harrison RJ, Cascio WE, Rappold AG. Cardiovascular and cerebrovascular emergency department visits associated with wildfire smoke exposure in California in 2015. J Am Heart Assoc. 2018; 7(8):e007492.

162. Widdicombe J, Lee LY. Airway reflexes, autonomic function, and cardiovascular responses. Environ Health Perspect. 2001;109(Suppl 4):579-84.

163. Williams AP, Abatzoglou JT, Gershunov A, Guzman-Morales J, Bishop DA, Balch JK, Lettenmaier DP. Observed impacts of anthropogenic climate change on wildfire in California. Earth's Future. 2019;7(8):892-910. 
164. Wylie BJ, Singh MP, Coull BA, Quinn A, Yeboah-Antwi K, Sabin L, Hamer DH, Singh N, MacLeod WB. Association between wood cooking fuel and maternal hypertension at delivery in central East India. Hypertens Pregnancy. 2015;34(3):355-68.

165. Yao J, Eyamie J, Henderson SB. Evaluation of a spatially resolved forest fire smoke model for population-based epidemiologic exposure assessment. J Expo Sci Environ Epidemiol. 2016;26(3):233-40

166. Yap PS, Garcia C. Effectiveness of residential wood-burning regulation on decreasing particulate matter levels and hospitalizations in the San Joaquin Valley Air Basin. Am J Public Health. 2015;105(4):772-8.

167. Young BN, Clark ML, Rajkumar S, Benka-Coker ML, Bachand A, Brook RD, Nelson TL, Volckens J, Reynolds SJ, L'Orange C, Good N, Koehler K, Africano $\mathrm{S}$, Osorto Pinel AB, Peel JL. Exposure to household air pollution from biomass cookstoves and blood pressure among women in rural Honduras: a cross-sectional study. Indoor Air. 2019:29(1):130-42.

168. Zeglinski MR, Turner CT, Zeng R, Schwartz C, Santacruz S, Pawluk MA, Zhao H, Chan AWH, Carlsten C, Granville DJ. Soluble wood smoke extract promotes barrier dysfunction in alveolar epithelial cells through a MAPK signaling pathway. Sci Rep. 2019;9(1):10027.

169. Zhang Y, Lim S, Sharples JJ. Wildfire occurrence patterns in ecoregions of New South Wales and Australian Capital Territory, Australia. Nat Hazards. 2017:87(1):415-35

\section{Publisher's Note}

Springer Nature remains neutral with regard to jurisdictional claims in published maps and institutional affiliations.

Ready to submit your research? Choose BMC and benefit from:

- fast, convenient online submission

- thorough peer review by experienced researchers in your field

- rapid publication on acceptance

- support for research data, including large and complex data types

- gold Open Access which fosters wider collaboration and increased citations

- maximum visibility for your research: over $100 \mathrm{M}$ website views per year

At $\mathrm{BMC}$, research is always in progress.

Learn more biomedcentral.com/submissions 